\title{
Contrasting effects of acidification and warming on dimethylsulfide concentrations during a temperate estuarine fall bloom mesocosm experiment
}

\author{
Robin Bénard ${ }^{1}$, Maurice Levasseur ${ }^{1}$, Michael Scarratt ${ }^{2}$, Sonia Michaud $^{2}$, Michel Starr $^{2}$, Alfonso Mucci $^{3}$, \\ Gustavo Ferreyra $^{4,5}$, Michel Gosselin ${ }^{4}$, Jean-Éric Tremblay ${ }^{1}$, Martine Lizotte ${ }^{1}$, and Gui-Peng Yang ${ }^{6}$ \\ ${ }^{1}$ Département de biologie, Université Laval, 1045 avenue de la Médecine, Québec, Québec G1V 0A6, Canada \\ ${ }^{2}$ Fisheries and Oceans Canada, Maurice Lamontagne Institute, P.O. Box 1000, Mont-Joli, Québec G5H 3Z4, Canada \\ ${ }^{3}$ Department of Earth and Planetary Sciences, McGill University, 3450 University Street, Montréal, \\ Québec H3A 2A7, Canada \\ ${ }^{4}$ Institut des sciences de la mer de Rimouski (ISMER), Université du Québec à Rimouski, 310 allée des Ursulines, \\ Rimouski, Québec G5L 3A1, Canada \\ ${ }^{5}$ Centro Austral de Investigaciones Científicas (CADIC), Consejo Nacional de Investigaciones Científicas y Técnicas, \\ Bernardo Houssay 200, 9410 Ushuaia, Tierra del Fuego, Argentina \\ ${ }^{6}$ Institute of Marine Chemistry, Ocean University of China, 238 Songling Road, Qingdao 266100, Shandong, China
}

Correspondence: Robin Bénard (robin.benard.1@ulaval.ca)

Received: 13 July 2018 - Discussion started: 22 August 2018

Revised: 11 January 2019 - Accepted: 30 January 2019 - Published: 21 March 2019

\begin{abstract}
The effects of ocean acidification and warming on the concentrations of dimethylsulfoniopropionate (DMSP) and dimethylsulfide (DMS) were investigated during a mesocosm experiment in the Lower St. Lawrence Estuary (LSLE) in the fall of 2014. Twelve mesocosms covering a range of $\mathrm{pH}_{\mathrm{T}}$ ( $\mathrm{pH}$ on the total hydrogen ion concentration scale) from 8.0 to 7.2 , corresponding to a range of $\mathrm{CO}_{2}$ partial pressures $\left(p \mathrm{CO}_{2}\right.$ ) from 440 to $2900 \mu \mathrm{atm}$, at two temperatures (in situ and $+5^{\circ} \mathrm{C} ; 10$ and $15^{\circ} \mathrm{C}$ ) were monitored during 13 days. All mesocosms were characterized by the rapid development of a diatom bloom dominated by Skeletonema costatum, followed by its decline upon the exhaustion of nitrate and silicic acid. Neither the acidification nor the warming resulted in a significant impact on the abundance of bacteria over the experiment. However, warming the water by $5^{\circ} \mathrm{C}$ resulted in a significant increase in the average bacterial production (BP) in all $15^{\circ} \mathrm{C}$ mesocosms as compared to $10^{\circ} \mathrm{C}$, with no detectable effect of $p \mathrm{CO}_{2}$ on BP. Variations in total DMSP $\left(\right.$ DMSP $_{t}=$ particulate + dissolved DMSP $)$ concentrations tracked the development of the bloom, although the rise in $\mathrm{DMSP}_{\mathrm{t}}$ persisted for a few days after the peaks in chlorophyll $a$. Average concentrations of DMSP $\mathrm{t}_{\mathrm{t}}$ were not affected by acidification or warming. Initially low concentrations of
\end{abstract}

DMS $\left(<1 \mathrm{nmol} \mathrm{L}^{-1}\right)$ increased to reach peak values ranging from 30 to $130 \mathrm{nmol} \mathrm{L}^{-1}$ towards the end of the experiment. Increasing the $p \mathrm{CO}_{2}$ reduced the averaged DMS concentrations by $66 \%$ and $69 \%$ at 10 and $15^{\circ} \mathrm{C}$, respectively, over the duration of the experiment. On the other hand, a $5^{\circ} \mathrm{C}$ warming increased DMS concentrations by an average of $240 \%$ as compared to in situ temperature, resulting in a positive offset of the adverse $p \mathrm{CO}_{2}$ impact. Significant positive correlations found between bacterial production and concentrations of DMS throughout our experiment point towards temperatureassociated enhancement of bacterial DMSP metabolism as a likely driver of the mitigating effect of warming on the negative impact of acidification on the net production of DMS in the LSLE and potentially the global ocean. 


\section{Introduction}

Dimethylsulfide (DMS) is ubiquitous in productive estuarine, coastal, and oceanic surface waters (Barnard et al., 1982; Iverson et al., 1989; Kiene and Service, 1991; Cantin et al., 1996; Kettle et al., 1999). With an estimated average $28.1 \mathrm{Tg}$ of sulfur $(\mathrm{S})$ being transferred to the atmosphere annually (Lana et al., 2011), DMS emissions constitute the largest natural source of tropospheric S (Lovelock et al., 1972; Andreae, 1990; Bates et al., 1992). The oxidation of atmospheric DMS yields hygroscopic sulfate $\left(\mathrm{SO}_{4}^{2-}\right)$ aerosols that directly scatter incoming solar radiation and act as nuclei upon which cloud droplets can condense and grow, thereby potentially impacting cloud albedo and the radiative properties of the atmosphere (Charlson et al., 1987; Andreae and Crutzen, 1997; Liss and Lovelock, 2007; Woodhouse et al., 2013). The scale of the impact of biogenic $\mathrm{SO}_{4}^{2-}$ particles on global climate, however, remains uncertain (Carslaw et al., 2010; Quinn and Bates, 2011; Quinn et al., 2017). The strength of DMS emissions depends on windand temperature-driven transfer processes (Nightingale et al., 2000) but mostly on its net production in the surface mixed layer of the ocean (Malin and Kirst, 1997). Net changes in the aqueous DMS inventory are largely governed by microbial food webs (see reviews by Simó, 2001; Stefels et al., 2007) whose productivity is potentially sensitive to modifications in the habitats that sustain them. Given the complexity of the biological cycling of DMS, understanding how climate change related stressors could impact the production of this climate-active gas is a worthy but formidable challenge.

DMS is produced, for the most part, from the enzymatic breakdown of dimethylsulfoniopropionate (DMSP) (Cantoni and Anderson, 1956), a metabolite produced by several groups of phytoplankton, with an extensive range in intracellular quotas between taxa (Keller, 1989; Stefels et al., 2007). Several species of the classes Haptophyceae and Dinophyceae are amongst the most prolific DMSP producers, but certain members of Bacillariophyceae (diatoms) and Chrysophyceae can also produce significant amounts of DMSP (Stefels et al., 2007). The biosynthesis of DMSP is highly constrained by abiotic factors and its up- or downregulation may allow cells to cope with environmental shifts in temperature, salinity, nutrients and light intensity (Kirst et al., 1991; Karsten et al., 1996; Sunda et al., 2002), while its de novo synthesis and exudation may also serve as a sink for excess carbon (C) and sulfur (S) under unfavorable growth conditions (Stefels, 2000). Beyond active exudation in healthy cells (Laroche et al., 1999), cellular or particulate DMSP (DMSP $\mathrm{p}_{\mathrm{p}}$ ) can be transferred to the water column as dissolved DMSP $\left(\right.$ DMSP $\left._{\mathrm{d}}\right)$ through viral lysis (Hill et al., 1998; Malin et al., 1998), autolysis (Nguyen et al., 1988; Stefels and Van Boeckel, 1993), and grazing by micro-, meso- and macro-zooplankton (Dacey and Wakeham, 1986; Wolfe and Steinke, 1996). The turnover rate of $\mathrm{DMSP}_{\mathrm{d}}$ in the water column is generally very rapid (a few hours to days) as this compound represents sources of $\mathrm{C}$ and reduced $\mathrm{S}$ for the growth of microbial organisms (Kiene and Linn, 2000). Heterotrophic bacteria mediate most of the turnover of S-DMSP $\mathrm{d}_{\mathrm{d}}$ through pathways that constrain the overall production of DMS: (1) enzymatic cleavage of $\mathrm{DMSP}_{d}$ that yields DMS; (2) demethylation/demethiolation of $\mathrm{DMSP}_{\mathrm{d}}$ that yields methanethiol (MeSH); (3) production of dissolved non-volatile $\mathrm{S}$ compounds, including $\mathrm{SO}_{4}^{2-}$, following oxidation of $\mathrm{DMSP}_{\mathrm{d}}$; (4) intracellular accumulation of $\mathrm{DMSP}_{\mathrm{d}}$ with no further metabolization (Kiene et al., 1999, 2000; Kiene and Linn, 2000; Yoch, 2002). A compilation of ${ }^{35} \mathrm{~S}$ DMSP $_{d}$ tracer studies conducted with natural microbial populations shows that microbial DMS yields rarely exceed $40 \%$ of consumed $\mathrm{DMSP}_{\mathrm{d}}$ in surface coastal and oceanic waters (see review table in Lizotte et al., 2017). Another potential fate of $\mathrm{DMSP}_{\mathrm{d}}$ is its uptake by non-DMSP producing eukaryotic phytoplankton such as certain diatoms (Vila-Costa et al., 2006b; Ruiz-González et al., 2012) and cyanobacteria such as Synechococcus and Prochloroccocus (Malmstrom et al., 2005; Vila-Costa et al., 2006b), but the overall turnover of $\mathrm{DMSP}_{\mathrm{d}}$ seems to be dominated by heterotrophic organisms.

Whereas the role of bacteria in the production of DMS via DMSP $_{\mathrm{d}}$ is well recognized, an increasing number of studies have shown that the phytoplankton-mediated enzymatic conversion of total DMSP $\left(\mathrm{DMSP}_{t}\right)$ into DMS can also be significant when communities are dominated by DMSP-lyase producing phytoplankton groups such as Dinophyceae and Haptophyceae (Niki et al., 2000; Steinke et al., 2002; Stefels et al., 2007; Lizotte et al., 2012), particularly under high doses of solar radiation (Toole and Siegel, 2004; Toole et al., 2006, 2008; Vallina et al., 2008). Removal processes of DMS from surface waters include photo-oxidation, bacterial degradation, and efflux across the air-sea interface which individually depends on several factors such as light intensity, wind velocity, the depth of the surface mixed layer, and the gross production of DMS (Brimblecombe and Shooter, 1986; Simó and Pedros-Alió, 1999; Nightingale et al., 2000; Hatton et al., 2004; Simó, 2004). Additionally, the biological and photochemical oxidation of dimethylsulfoxide (DMSO) is an important sink for DMS, while DMSO reduction represents a DMS source (Stefels et al. 2007; Spiese et al., 2009; Asher et al., 2011). Overall, production and turnover of DMS and its precursor DMSP are unequivocally linked with microbial activity, both autotrophic and heterotrophic. The associated biological processes and interactions amongst these microorganisms have been shown to be sensitive to fluctuations in abiotic factors and may thus be further modulated by multiple drivers of climate change.

Since the pre-industrial era, atmospheric $\mathrm{CO}_{2}$ concentrations have risen from $280 \mathrm{ppm}$, and, according to the results of the global ocean circulation models under the condition of the business-as-usual scenario RCP 8.5, are expected to reach $850-1370 \mathrm{ppm}$ by 2100 (IPCC, 2013). The oceans have already absorbed about $28 \%$ of the anthropogenic $\mathrm{CO}_{2}$ emitted into the atmosphere (Le Quéré et al., 2015), leading to a 
$\mathrm{pH}$ decrease of 0.11 units in surface waters (Gattuso et al., 2015), a phenomenon called ocean acidification (OA). An additional decrease in $\mathrm{pH}$ by $0.3-0.4$ units is expected by the end of this century, and could reach 0.8 units by 2300 (Caldeira and Wickett, 2005; Doney et al., 2009; Feely et al., 2009). In addition to the oceanic sink, a similar fraction of anthropogenic $\mathrm{CO}_{2}$ emissions has been captured by terrestrial vegetation, while the anthropogenic $\mathrm{CO}_{2}$ remaining (45\% of total emissions) in the atmosphere (Le Quéré et al., 2013) has led to an estimated increased greenhouse effect of $0.3-0.6 \mathrm{~W} \mathrm{~m}^{-2}$ globally over the past 135 years (Roemmich et al., 2015). Ninety percent of this excess heat has been absorbed by the ocean, increasing sea surface temperatures (SST) by $\sim 0.1^{\circ} \mathrm{C}$ per decade since 1951, and could increase SST by $3-5^{\circ} \mathrm{C}$ before 2100 (IPCC, 2013). Leading experts in the field of global change have called upon the scientific community to address critical knowledge gaps, among which a top priority remains the assessment of the impact of multiple environmental stressors on marine microorganisms (Riebesell and Gattuso, 2015).

The sensitivity of natural planktonic assemblages to OA, along with their production of DMSP and DMS, has been investigated in several experimental studies (see review table in Hussherr et al., 2017). The majority of these experiments have shown a decrease in both DMSP and DMS concentrations with increasing $p \mathrm{CO}_{2}$ (Hopkins et al., 2010; Avgoustidi et al., 2012; Park et al., 2014; Webb et al., 2015). The decrease in DMSP production has largely been attributed to the deleterious impact of decreasing $\mathrm{pH}$ on the coccolithophore Emiliania huxleyi, the dominant DMSP producer in several of these studies. Nevertheless, OA does not always result in a concomitant decrease in DMSP and DMS production. For example, the $p \mathrm{CO}_{2}$-induced decrease in DMS reported by Archer et al. (2013) in Arctic waters was accompanied by an increase in DMSP concentrations, indicating that DMS production is at least partly dependent on the turnover of DMSP, rather than on the DMSP pool. A modeling study showed that the specific implementation of the negative effect of OA on DMS net production in a coupled ocean-atmosphere model reduces global DMS production by $18 \pm 3 \%$, resulting in an additional warming of $0.23-0.48 \mathrm{~K}$ by 2100 under the A1B scenario (Six et al., 2013). Schwinger et al. (2017) further showed that the OA-induced decreases in oceanic DMS emissions could result in a transient global warming of $0.30 \mathrm{~K}$, mostly resulting from a reduction of cloud albedo. These first attempts to model the potential effect of OA on climate through its impact on DMS oceanic production show that OA may significantly affect climate by reducing marine emissions of DMS but also highlight the importance of carefully assessing the robustness of the DMS-OA negative relationship. This is particularly relevant considering that some experiments reveal a neutral or positive effect of increasing $p \mathrm{CO}_{2}$ on DMS net production (Vogt et al., 2008; Kim et al., 2010; Hopkins and Archer, 2014). Regional or seasonal differences in phytoplankton taxonomy, microzoo- plankton grazing, and bacterial activity have been proposed as key drivers of the discrepancies between these experimental results.

Whereas studies of the impact of OA on DMS cycling have gained momentum, the importance of assessing how combined drivers of change may impact the structure and the functioning of ocean ecosystems, using multifactorial approaches, is now increasingly recognized (Boyd et al., 2015, 2018; Riebesell and Gattuso, 2015; Gunderson et al., 2016). Thus far, only two mesocosm studies assessed the combined effect of OA and warming on DMS dynamics by natural plankton assemblages. The two studies, both conducted with coastal waters, led to contrasting results. The first study showed an $80 \%$ increase in DMS concentrations under high $p \mathrm{CO}_{2}$ conditions ( $900 \mathrm{ppm}$ vs. $400 \mathrm{ppm}$ ), and a reduction by $20 \%$ of this stimulating effect when the increase in $p \mathrm{CO}_{2}$ was accompanied by a $3{ }^{\circ} \mathrm{C}$ warming (Kim et al., 2010). However, the absence of a specific stand-alone warming treatment did not allow the authors to assess the sole impact of temperature on DMS net production. The second study showed decreasing DMS concentrations under both acidification and greenhouse conditions, with the lowest DMS concentrations measured under combined acidification and warming treatments (Park et al., 2014). The authors attributed these contrasting responses to differences in the phytoplankton assemblages, DMSP-related algal physiological characteristics, and microzooplankton grazing. Nevertheless, questions remain as to the combined effect of $p \mathrm{CO}_{2}$ and warming on DMS net production since the temperature treatments were not conducted over the full range of $p \mathrm{CO}_{2}$ tested (Kim et al., 2010; Park et al., 2014).

The combined influence of acidification and warming on the dynamics of the St. Lawrence Estuary phytoplankton fall bloom was investigated during a full factorial mesocosm experiment (Bénard et al., 2018a). During this experiment, a bloom of Skeletonema costatum developed in all mesocosms, independently of the $p \mathrm{CO}_{2}$ gradient (from 440 to $2900 \mu \mathrm{atm})$ and temperatures tested $\left(10\right.$ and $\left.15^{\circ} \mathrm{C}\right)$. The increase in $p \mathrm{CO}_{2}$ had no influence on the bloom, but warming accelerated the growth rate of the diatoms and hastened the decline of the bloom (Bénard et al., 2018a). Here, we report on the impacts of acidification and warming on DMSP and DMS concentrations with a focus on the dynamics of heterotrophic bacteria, a component of the marine food web known to affect the turnover of DMSP and DMS.

\section{Materials and methods}

\subsection{Mesocosm setup}

The mesocosm experimental setup is described in detail in Bénard et al. (2018a). Briefly, mesocosm experiments were conducted at the ISMER marine research station of Rimouski (Québec, Canada) in the fall of 2014. The twelve 
$2600 \mathrm{~L}$ cylindrical $(2.67 \mathrm{~m} \times 1.4 \mathrm{~m})$, conical bottom, mesocosms were housed in two temperature-controlled, fullsize shipping containers each containing six mesocosms (Aquabiotech Inc., Québec, Canada). Each mesocosm is mixed by a propeller secured near the top of the enclosure to ensure homogeneity of the water column. The mesocosms are sealed by a Plexiglas cover transmitting $50 \%-85 \%$ of solar UVB (280-315 nm), $85 \%-90 \%$ of UVA (315-400 nm), and $90 \%$ of photosynthetically active radiation (PAR; 400$700 \mathrm{~nm}$ ) of the natural incident light. Independent temperature probes (AQBT-Temperature sensor, accuracy $\pm 0.2{ }^{\circ} \mathrm{C}$ ) were installed in each mesocosm, recording temperature every $15 \mathrm{~min}$ and either triggering a resistance heater (Process Technology TTA1.8215) or a glycol refrigeration system activated by an automated pump. The $\mathrm{pH}$ of the mesocosms was measured every 15 min by Hach $^{\circledR}$ PD1P1 probes $\left( \pm 0.02 \mathrm{pH}\right.$ units) linked to $\mathrm{Hach}^{\circledR}$ SC200 controllers. To maintain $\mathrm{pH}$, two reservoirs of artificial seawater were equilibrated with pure $\mathrm{CO}_{2}$ before the start of the experiment and positive deviations from the target $\mathrm{pH}$ values in each mesocosm activated peristaltic pumps that injected the $\mathrm{CO}_{2}$ supersaturated seawater into the mesocosm water. This control system was able to maintain the $\mathrm{pH}$ in the mesocosms within $\pm 0.02 \mathrm{pH}$ units of the targeted values during the initial bloom development by lowering the $\mathrm{pH}$, but it could not increase the $\mathrm{pH}$ during the declining phase of the bloom.

\subsection{Experimental approach}

Prior to the onset of the experiment, all the mesocosms were meticulously washed with diluted Virkon ${ }^{\mathrm{TM}}$, an antiviral and anti-bacterial solution, according to the manufacturer's instructions (Antec International Limited), and thoroughly rinsed. The experimental approach is also detailed in Bénard et al. (2018a). To fill the mesocosms, water from $\sim 5 \mathrm{~m}$ depth was collected near the Rimouski harbour $\left(48^{\circ} 28^{\prime} 39.9^{\prime \prime} \mathrm{N}, 68^{\circ} 31^{\prime} 03.0^{\prime \prime} \mathrm{W}\right)$ on the 27 September 2014 (day -5$)$. Initial conditions were practical salinity $=26.52$, temperature $=10^{\circ} \mathrm{C}$, nitrate $\left(\mathrm{NO}_{3}^{-}\right)=12.8 \pm 0.6 \mu \mathrm{mol} \mathrm{L}{ }^{-1}$, silicic acid $\left(\mathrm{Si}(\mathrm{OH})_{4}\right)=16 \pm 2 \mu \mathrm{mol} \mathrm{L}^{-1}$, and soluble reactive phosphate $(\mathrm{SRP})=1.4 \pm 0.3 \mu \mathrm{mol} \mathrm{L}^{-1}$. Following its collection, the water was screened through a $250 \mu \mathrm{m}$ mesh while the mesocosms were simultaneously gravity-filled by a custom made "octopus" tubing system. The initial in situ temperature of $10^{\circ} \mathrm{C}$ was maintained in all mesocosms for the first $24 \mathrm{~h}$ (day -4$)$. On day -3 , the six mesocosms in one of the containers were gradually heated to $15^{\circ} \mathrm{C}$ while the mesocosms in the other container were maintained at $10^{\circ} \mathrm{C}$. No manipulations were performed on day -2 to avoid excessive stress, and acidification was carried out on day -1 . The mesocosms were initially set to cover a gradient of $\mathrm{pH}_{\mathrm{T}}$ (total proton concentration scale) of $\sim 8.0$ to 7.2 corresponding to a range of $p \mathrm{CO}_{2}$ from 440 to $2900 \mu \mathrm{atm}$. Two mesocosms, one in each container (at each temperature), were not $\mathrm{pH}$-controlled to assess the effect of freely fluctuating $\mathrm{pH}$ condition. These two mesocosms were called drifters since the in situ $\mathrm{pH}$ was allowed to drift over time throughout the bloom development. To achieve the initially targeted $\mathrm{pH}_{\mathrm{T}}$, $\mathrm{CO}_{2}$-saturated artificial seawater was added to mesocosms $\mathrm{M} 1, \mathrm{M} 3, \mathrm{M} 5, \mathrm{M} 7, \mathrm{M} 8, \mathrm{M} 10\left(\mathrm{pH}_{\mathrm{T}}\right.$ 7.2-7.6) while mesocosms M2, M4, M6, M9, M11, M12 ( $\mathrm{pH}_{\mathrm{T}}$ 7.8-8.0 and the drifters) were openly mixed to allow $\mathrm{CO}_{2}$ degassing. Then, the automatic system controlling the occasional addition of $\mathrm{CO}_{2}-$ saturated artificial seawater maintained the $\mathrm{pH}$ equal or below the targeted $\mathrm{pH}$, except for the drifters.

\subsection{Seawater analysis}

Daily sampling of the mesocosms was carried out between 05:00 and 08:00 every day (EDT) as described in Bénard et al. (2018a). Samples for carbonate chemistry, nutrients, DMSP, and DMS were collected directly from the mesocosms prior to filling of $20 \mathrm{~L}$ carboys from which seawater for the determination of chlorophyll $a(\mathrm{Chl} a)$, bacterial abundance, and bacterial production (BP) was subsampled. Samples were collected directly from the mesocosms and the artificial seawater tank on days $-3,3$, and 13 for practical salinity determinations. The samples were collected in $250 \mathrm{~mL}$ plastic bottles and stored in the dark until analysis was carried out on a Guildline Autosal 8400B salinometer in the months following the experiment.

\subsubsection{Carbonate chemistry and nutrients}

Analytical methods used to determine the carbonate parameters are described in detail in Bénard et al. (2018a). Briefly, $\mathrm{pH}$ was determined every day by transferring samples from the mesocosms to $125 \mathrm{~mL}$ plastic bottles without headspace. The samples were analyzed within hours of collection on a Hewlett-Packard UV-Visible diode array spectrophotometer (HP-8453A) and a $5 \mathrm{~cm}$ quartz cell using phenol red (PR; Robert-Baldo et al., 1985) and $m$-cresol purple (mCP; Clayton and Byrne, 1993) as indicators after equilibration to $25.0 \pm 0.1^{\circ} \mathrm{C}$ in a thermostated bath. The $\mathrm{pH}$ on the total proton scale $\left(\mathrm{pH}_{\mathrm{T}}\right)$ was calculated according to Byrne (1987), with the salinity of the sample and the $\mathrm{HSO}_{4}^{-}$association constants given by Dickson (1990). The reproducibility of $\mathrm{pH}$ measurements, based on replicate measurements of the same samples and values derived from both indicators, was on the order of 0.003. Samples for total alkalinity (TA) were collected every 3-4 days in $250 \mathrm{~mL}$ glass bottles to which a few crystals of $\mathrm{HgCl}_{2}$ were added before sealing with ground glass stoppers and Apiezon ${ }^{\circledR}$ Type-M high-vacuum grease. The TA determinations were carried out within 1 day of sampling by open-cell automated potentiometric titration (Titrilab 865, Radiometer ${ }^{\circledR}$ ) with a pH combination electrode $\left(\mathrm{pHC} 2001, \operatorname{Red} \operatorname{Rod}^{\circledR}\right)$ and a dilute $(0.025 \mathrm{M}) \mathrm{HCl}$ titrant solution calibrated against Certified Reference Materials (CRM Batch\#94, provided by A. G. Dickson, Scripps Institute of Oceanography, La Jolla, USA). The average relative error, 
calculated from the average relative standard deviation on replicate standards and sample analyses, was $<0.15 \%$. The computed $\mathrm{pH}_{\mathrm{T}}$ at $25^{\circ} \mathrm{C}$, measured TA, silicic acid, and SRP concentrations were used to calculate the in situ $\mathrm{pH}_{\mathrm{T}}, p \mathrm{CO}_{2}$, and saturation state of the water in each mesocosm using $\mathrm{CO}_{2}$ SYS (Pierrot et al., 2006) and the carbonic acid dissociation constants of Cai and Wang (1998).

The samples for the determination of $\mathrm{NO}_{3}^{-}, \mathrm{Si}(\mathrm{OH})_{4}$, and SRP were filtered through Whatman GF/F filters, collected in acid-washed polyethylene tubes, and stored at $-20^{\circ} \mathrm{C}$. Analysis was carried out using a Bran and Luebbe Autoanalyzer III using the colorimetric methods of Hansen and Koroleff (2007). The analytical detection limit was $0.03 \mu \mathrm{mol} \mathrm{L}-1$ for $\mathrm{NO}_{3}^{-}$plus nitrite $\left(\mathrm{NO}_{2}^{-}\right), 0.02 \mu \mathrm{mol} \mathrm{L}^{-1}$ for $\mathrm{NO}_{2}^{-}, 0.1 \mu \mathrm{mol} \mathrm{L}^{-1}$ for $\mathrm{Si}(\mathrm{OH})_{4}$, and $0.05 \mu \mathrm{mol} \mathrm{L}^{-1}$ for SRP.

\subsubsection{Biological variables}

Chl $a$ determination methods are presented in Bénard et al. (2018a). Succinctly, duplicate $100 \mathrm{~mL}$ samples were filtered onto Whatman GF/F filters. The filters were soaked in a $90 \%$ acetone solution at $4{ }^{\circ} \mathrm{C}$ in the dark for $24 \mathrm{~h}$; the solution was then analyzed by a 10-AU Turner Designs fluorometer (acidification method: Parsons et al., 1984). The analytical detection limit for Chl $a$ was $0.05 \mu \mathrm{g} \mathrm{L}-1$.

Samples for the determination of free-living heterotrophic bacteria were kept in sterile cryogenic polypropylene vials and fixed with glutaraldehyde Grade I (final concentration $=0.5 \%$, Sigma Aldrich; Marie et al., 2005). Duplicate samples were placed at $4{ }^{\circ} \mathrm{C}$ in the dark for $30 \mathrm{~min}$, then frozen at $-80^{\circ} \mathrm{C}$ until analysis by a FACS Calibur flow cytometer (Becton Dickinson) equipped with a $488 \mathrm{~nm}$ argon laser. Before enumeration, the samples were stained with SYBR Green I ( $0.1 \%$ final concentration, Invitrogen Inc.) to which $600 \mu \mathrm{L}$ of a Tris-EDTA $10 \times$ buffer of $\mathrm{pH} 8$ were added (Laboratoire MAT; Belzile et al., 2008). Fluoresbrite beads (diameter $1 \mu \mathrm{m}$, Polysciences) were also added to the sample as an internal standard. The green fluorescence of SYBR Green I was measured at $525 \pm 5 \mathrm{~nm}$. Bacterial abundance was determined as the sum of low and high nucleic (LNA and HNA) counts (Annane et al., 2015).

Bacterial production was estimated in each mesocosm except the drifters on days $0,2,4,6,8,10,11$, and 13 by measuring incorporation rates of tritiated thymidine $\left({ }^{3} \mathrm{H}-\mathrm{TdR}\right)$, using an incubation and filtration protocol based on Fuhrman and Azam (1980, 1982). Twenty $\mathrm{mL}$ water subsamples were transferred from glass Erlenmeyers to five sterile glass vials, three as "measured" values and two as blanks. In all blank vials, $0.2 \mathrm{~mL}$ of formaldehyde $37 \%$ was added immediately after the sampling to stop all biological activities. Then, $1 \mathrm{~mL}$ of ${ }^{3} \mathrm{H}-$ TdR solution $\left(4 \mu \mathrm{mol} \mathrm{L}^{-1}\right)$, prepared from commercial solution (63 Curie $\mathrm{mmol}^{-1}$; $1{\mathrm{mCurie} \mathrm{mL}^{-1}, 10 \mu \mathrm{mol} \mathrm{L}}^{-13} \mathrm{H}$ TdR, MP Biomedicals), was added in all vials. Samples were incubated for $2.5 \mathrm{~h}$ at experimental temperatures ( 10 or $15^{\circ} \mathrm{C}$ ), and then $0.2 \mathrm{~mL}$ of formaldehyde $37 \%$ was immediately added in the three "measure" vials. Bacteria were then collected by filtration (diameter $25 \mathrm{~mm} ; 0.2 \mu \mathrm{m}$ porosity) and filters were treated according to Fuhrman and Azam (1980, 1982). ${ }^{3} \mathrm{H}-\mathrm{TdR}$ incorporation was measured using a scintillation counter (Beckman LS5801) and results were expressed in dpm. Blank values were subtracted from "measured" values to remove background radioactivity. ${ }^{3} \mathrm{H}-\mathrm{TdR}$ incorporation rates were converted into mole of ${ }^{3} \mathrm{H}-\mathrm{TdR}$ incorporated per unit of volume and time, before converting to rate of carbon production using the carbon conversion factor of Bell (1993).

\subsubsection{DMSP and DMS concentrations}

For the quantification of $\mathrm{DMSP}_{\mathrm{t}}$, duplicate $3.5 \mathrm{~mL}$ samples of seawater were collected into $5 \mathrm{~mL}$ polyethylene tubes. Samples were preserved by adding $50 \mu \mathrm{L}$ of a $50 \%$ sulfuric acid solution $\left(\mathrm{H}_{2} \mathrm{SO}_{4}\right)$ to the tubes before storage at $4{ }^{\circ} \mathrm{C}$ in the dark until analysis in the following months. Samples for the quantification of $\mathrm{DMSP}_{\mathrm{d}}$ were taken daily, but a technical problem during storage and transport of the samples led to a loss of all samples. To quantify $\mathrm{DMSP}_{\mathrm{t}}, 1 \mathrm{~mL}$ of $\mathrm{NaOH}(5 \mathrm{M})$ was injected into a purge and trap (PnT) system prior to the $3.5 \mathrm{~mL}$ sample to hydrolyze DMSP into DMS following a mole-to-mole conversion. Ultrapure helium was used to bubble the heated chamber $\left(70^{\circ} \mathrm{C} ; 50 \pm 5 \mathrm{~mL} \mathrm{~min}^{-1}\right.$; $4 \mathrm{~min}$ ) trapping the gas sample in a loop immersed in liquid nitrogen. The loop was then heated in a water bath to release the trapped sample and analyzed using a Varian 3800 Gas Chromatograph equipped with a pulsed flame photometric detector (PFPD, Varian 3800) and a detection limit of $0.9 \mathrm{nmol} \mathrm{L}^{-1}$ (Scarratt et al., 2000; Lizotte et al., 2012). DMSP concentrations were determined against a calibration curve using standardized DMSP samples prepared by diluting known concentrations of DMSP standard (Research Plus Inc.) into deionized water and analyzed following the same methodology.

Samples for the quantification of DMS were directly collected from the mesocosms into $20 \mathrm{~mL}$ glass vials with a butyl septa and aluminum crimp. The samples were kept in the dark at $4{ }^{\circ} \mathrm{C}$ until analysis was carried out within hours of collection by injecting the $20 \mathrm{~mL}$ sample in the PnT system described above, without the prior addition of $\mathrm{NaOH}$. DMS concentrations were calculated against microliter injections of DMS diluted with ultrapure helium using a permeation tube (Certified Calibration by Kin-Tek Laboratories Inc.; Lizotte et al., 2012).

\subsection{Statistical analyses}

The statistical analyses were performed using the nlme package in R (R Core Team, 2016). The data were analyzed using a general least squares (gls) approach to test the linear effects 
of the two treatments (temperature, $p \mathrm{CO}_{2}$ ) and their interaction on the variables (Paul et al., 2016; Hussherr et al., 2017; Bénard et al., 2018a). The analyses were conducted on the averages of the measured parameters over the whole duration of the experiment, and separate regressions for $p \mathrm{CO}_{2}$ were performed for each temperature when the latter had a significant effect. The residuals were checked for normality using a Shapiro-Wilk test $(p>0.05)$, and data were transformed (square root or natural logarithm) if necessary. In addition, squared Pearson's correlation coefficients $\left(r^{2}\right)$ with a significance level of 0.05 were used to evaluate correlations between key variables.

\section{Results}

\subsection{Physical and chemical conditions during the experiments}

The practical salinity was $26.52 \pm 0.03$ on day -4 in all mesocosms and remained constant throughout the experiment, averaging $26.54 \pm 0.02$ on day 13 (Bénard et al., 2018a). The temperature of the mesocosms in each container remained within $\pm 0.1{ }^{\circ} \mathrm{C}$ of the target temperature throughout the experiment and averaged $10.04 \pm 0.02{ }^{\circ} \mathrm{C}$ for mesocosms M1 through M6, and $15.0 \pm 0.1{ }^{\circ} \mathrm{C}$ for mesocosms M7 through M12 (Fig. 1a). The $\mathrm{pH}_{\mathrm{T}}$ remained relatively stable throughout the experiment in the $\mathrm{pH}$-controlled treatments, but decreased slightly as the experiment progressed, deviating by an average of $-0.14 \pm 0.07$ units relative to the target $\mathrm{pH}_{\mathrm{T}}$ on the last day (Fig. 1b). The $\mathrm{pH}$ variations corresponded to changes in $p \mathrm{CO}_{2}$ from an average of $1340 \pm 150 \mu \mathrm{atm}$ on day -3 , and ranged from 564 to $2902 \mu$ atm at $10^{\circ} \mathrm{C}$ and from 363 to $2884 \mu$ atm at $15^{\circ} \mathrm{C}$ on day 0 following the acidification (Fig. 1c). The in situ $\mathrm{pH}_{\mathrm{T}}$ in the drifters (M6 and M11) increased from 7.896 and 7.862 on day 0 , at 10 and $15^{\circ} \mathrm{C}$, respectively, to 8.307 and 8.554 on day 13 , reflecting the balance between $\mathrm{CO}_{2}$ uptake and metabolic $\mathrm{CO}_{2}$ production over the duration of the experiment. On the last day, $p \mathrm{CO}_{2}$ in all mesocosms ranged from 186 to $3695 \mu$ atm at $10^{\circ} \mathrm{C}$ and from 90 to 3480 uatm at $15^{\circ} \mathrm{C}$.

Nitrate $\left(\mathrm{NO}_{3}^{-}\right)$and silicic acid $\left(\mathrm{Si}(\mathrm{OH})_{4}\right)$ concentrations averaged $9.1 \pm 0.5$ and $13.4 \pm 0.3 \mu \mathrm{mol} \mathrm{L}^{-1}$ on day 0 , respectively (Bénard et al., 2018a). The two nutrients displayed a similar temporal depletion pattern following the development of the phytoplankton bloom. $\mathrm{NO}_{3}^{-}$concentrations reached undetectable levels $\left(<0.03 \mu \mathrm{mol} \mathrm{L}^{-1}\right)$ in all mesocosms by day 5 . Likewise, $\mathrm{Si}(\mathrm{OH})_{4}$ fell below the detection limit $\left(<0.1 \mu \mathrm{mol} \mathrm{L}^{-1}\right)$ between days 1 and 5 in all mesocosms except for those whose $\mathrm{pH}_{\mathrm{T}}$ was set at 7.2 and 7.6 at $10^{\circ} \mathrm{C}$ (M5 and M3) and in which $\mathrm{Si}(\mathrm{OH})_{4}$ depletion occurred on day 9 .
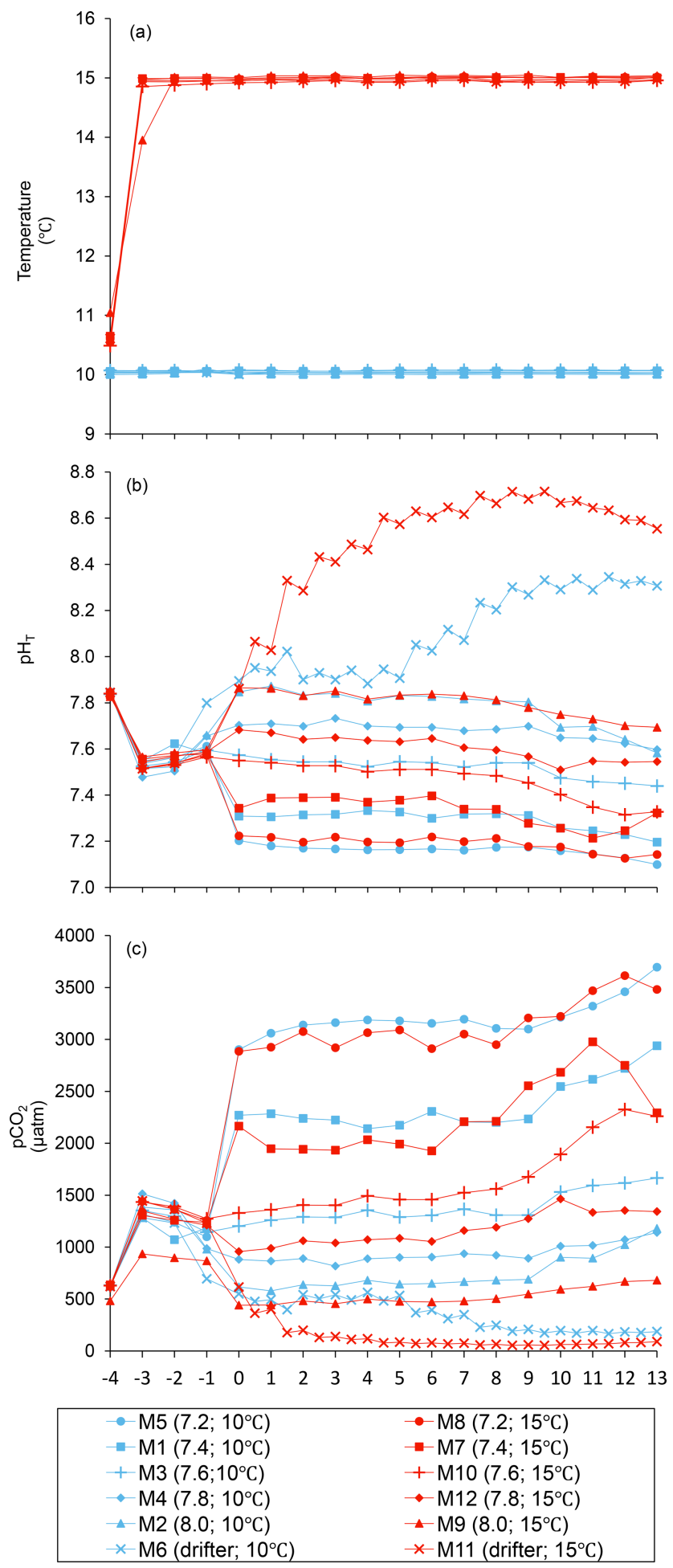

Figure 1. Temporal variations over the course of the experiment for (a) temperature, (b) $\mathrm{pH}_{\mathrm{T}}$, and (c) $p \mathrm{CO}_{2}$. For symbol attribution to treatments, see the legend. Adapted from Bénard et al. (2018a). 

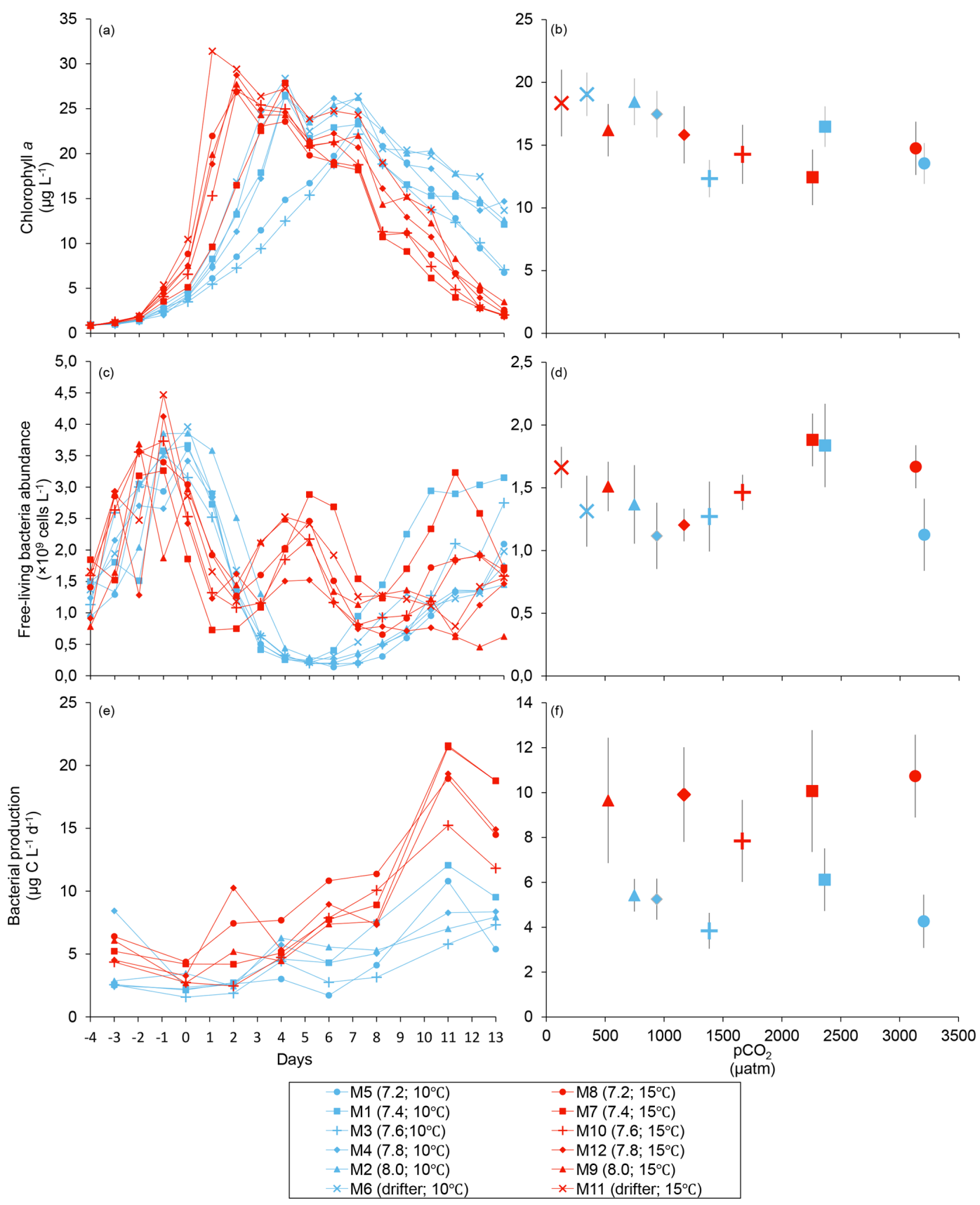

Figure 2. Temporal variations and averages over the course of the experiment (day 0 to day 13) for (a-b) chlorophyll $a$ (adapted from Bénard et al., 2018a), (c-d) free-living bacterial abundance, and (e-f) bacterial production. For symbol attribution to treatments, see the legend.

\subsection{Phytoplankton, bacterial abundance, and production}

Chl $a$ concentrations were below $1 \mu \mathrm{g} \mathrm{L}-1$ following the filling of the mesocosms (day -4), and had already increased to an average of $5.9 \pm 0.6 \mu \mathrm{g} \mathrm{L}{ }^{-1}$ on day 0 (Fig. 2a). At $10^{\circ} \mathrm{C}$, Chl $a$ quickly increased to reach maximum concentrations around $27 \pm 2 \mu \mathrm{gL}^{-1}$ on day $3 \pm 2$, and decreased progressively until the end of the experiment. Increasing the tem- perature by $5{ }^{\circ} \mathrm{C}$ resulted in a more rapid development of the bloom and a speedier decrease in Chl $a$ concentrations during the declining phase of the bloom. The maximum $\mathrm{Chl} a$ concentration reached at the peak of the bloom was, however, not significantly affected by the difference in temperature. We found no significant effect of the $p \mathrm{CO}_{2}$ gradient on the mean Chl $a$ concentrations measured over days $0-13$, nor during the development phase and the declining phase of 
Table 1. Results of the generalized least squares models (gls) tests for the effects of temperature, $p \mathrm{CO}_{2}$, and their interaction over the duration of the experiment (day 0 to day 13). Separate analyses with $p \mathrm{CO}_{2}$ as a continuous factor were performed when temperature had a significant effect. Averages of bacterial abundance and production, DMSP $\mathrm{t}_{\mathrm{t}}, \mathrm{DMS}$, Chl $a$-normalized $\mathrm{DMSP}_{\mathrm{t}}$ and $\mathrm{DMS}_{\text {concentrations, }}$ and DMS : DMSP $_{t}$ ratios are presented with corresponding degrees of freedom (df). Natural logarithm transformation is indicated when necessary. Significant results are in bold.

\begin{tabular}{|c|c|c|c|c|}
\hline Response variable & Factor & df & $t$-value & $p$-value \\
\hline \multirow{3}{*}{$\begin{array}{l}\text { Free-living bacterial abundance } \\
\left(\times 10^{9} \text { cells } \mathrm{L}^{-1}\right)\end{array}$} & Temperature & 8 & 0.635 & 0.543 \\
\hline & $p \mathrm{CO}_{2}$ & 8 & -0.083 & 0.936 \\
\hline & $p \mathrm{CO}_{2} \times$ temperature & 8 & 0.221 & 0.830 \\
\hline \multirow{3}{*}{$\begin{array}{l}\text { Bacterial production } \\
\left(\mu \mathrm{g} \mathrm{CL} L^{-1} \mathrm{~d}^{-1}\right)\end{array}$} & Temperature & 6 & 2.454 & $\mathbf{0 . 0 5 0}$ \\
\hline & $p \mathrm{CO}_{2}\left(10^{\circ} \mathrm{C}\right)$ & 3 & -0.272 & 0.803 \\
\hline & $p \mathrm{CO}_{2}\left(15^{\circ} \mathrm{C}\right)$ & 3 & 0.746 & 0.510 \\
\hline \multirow{3}{*}{$\begin{array}{l}\operatorname{DMSP}_{t} \\
\left(\mathrm{nmol} \mathrm{L}^{-1}\right)\end{array}$} & Temperature & 8 & 0.509 & 0.625 \\
\hline & $p \mathrm{CO}_{2}$ & 8 & -0.767 & 0.465 \\
\hline & $p \mathrm{CO}_{2} \times$ temperature & 8 & 0.134 & 0.897 \\
\hline \multirow{3}{*}{$\begin{array}{l}\text { DMS } \\
\left(\mathrm{nmol} \mathrm{L}^{-1}\right)\end{array}$} & Temperature & 8 & 6.822 & $<0.001$ \\
\hline & $p \mathrm{CO}_{2}\left(10^{\circ} \mathrm{C}\right)$ & 4 & -4.483 & 0.011 \\
\hline & $p \mathrm{CO}_{2}\left(15^{\circ} \mathrm{C}\right)$ & 4 & -3.799 & 0.019 \\
\hline \multirow{3}{*}{$\begin{array}{l}\operatorname{DMSP}_{\mathrm{t}}: \text { Chl } a \text { ratio } \\
\left(\mathrm{nmol}(\mu \mathrm{g} \mathrm{Chl} a)^{-1}\right)\end{array}$} & Temperature & 8 & 2.627 & $\mathbf{0 . 0 3 0}$ \\
\hline & $p \mathrm{CO}_{2}$ & 8 & 0.123 & 0.908 \\
\hline & $p \mathrm{CO}_{2} \times$ temperature & 8 & 0.621 & 0.568 \\
\hline \multirow{3}{*}{$\begin{array}{l}\text { DMS : Chl } a \text { ratio } \\
\left(\operatorname{nmol}(\mu \mathrm{g} \mathrm{Chl} a)^{-1}\right)\end{array}$} & Temperature & 8 & 5.225 & $<0.001$ \\
\hline & $p \mathrm{CO}_{2}\left(10^{\circ} \mathrm{C}\right)$ & 4 & -1.373 & 0.242 \\
\hline & $p \mathrm{CO}_{2}\left(15^{\circ} \mathrm{C}\right)$ & 4 & -2.227 & 0.090 \\
\hline \multirow[t]{3}{*}{$\log \left(\mathrm{DMS}: \mathrm{DMSP}_{\mathrm{t}}\right)$} & Temperature & 8 & 5.131 & $<0.001$ \\
\hline & $p \mathrm{CO}_{2}\left(10^{\circ} \mathrm{C}\right)$ & 4 & -1.844 & 0.139 \\
\hline & $p \mathrm{CO}_{2}\left(15^{\circ} \mathrm{C}\right)$ & 4 & $-\mathbf{3 . 1 3 8}$ & 0.035 \\
\hline
\end{tabular}

the bloom as described in Bénard et al. (2018a) (Fig. 2a-b; Table 1).

The free-living bacterial abundance was $1.2 \times 10^{9}$ cells $\mathrm{L}^{-1}$ on day -4 , and increased rapidly to reach $3.1 \pm 0.6 \times 10^{9}$ cells $\mathrm{L}^{-1}$ on day 0 (Fig. $2 \mathrm{c}$ ). This initial increase in abundance probably resulted from the release of dissolved organic matter (DOM) during pumping of the seawater and filling of the mesocosms. The subsequent decrease in bacterial abundance during the development phase of the bloom suggests that the initial pool of DOM was fully utilized and that freshly released DOM was scarce. As expected, bacterial abundance increased during the declining phase of the bloom at $10^{\circ} \mathrm{C}$. Under warmer conditions, bacterial abundance decreased earlier during the initial bloom development than was observed at $10^{\circ} \mathrm{C}$, but was also marked by an earlier peak during the decline of the bloom, followed by a second, more variable peak in abundance. These variations in abundances probably reflect changes in the balance between bacterial growth and loss by grazing. When averaged over the experiment, we observed no effect of the treatments on the mean bacterial abundance (Fig. 2c-d; Table 1). At $10^{\circ} \mathrm{C}$, bacterial production was low at the beginning of the experiment and increased gradually during the development and declining phases of the bloom to reach peaks values of $9.3 \pm 0.9 \mu \mathrm{g} \mathrm{CL}^{-1} \mathrm{~d}^{-1}$ (Fig. 2e). Bacterial production increased faster at $15^{\circ} \mathrm{C}$ and reached maximal production rates of $19 \pm 1 \mu \mathrm{g} \mathrm{C} \mathrm{L}^{-1} \mathrm{~d}^{-1}$ on day 11 . Results of the gls model show no effect of the $p \mathrm{CO}_{2}$ gradient on bacterial production, but a positive effect of warming was observable throughout the experiment (Fig. 2f; Table 1).

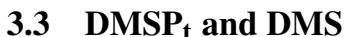

At in situ temperature, $\mathrm{DMSP}_{\mathrm{t}}$ concentrations averaged $9 \pm$ $2 \mathrm{nmol} \mathrm{L}^{-1}$ on day 0 and increased regularly in all mesocosms up to day 10 before they plateaued or slightly decreased over the last 2-3 days (Fig. 3a). These results reveal that DMSP accumulation persisted for several days after the bloom peaks, to reach a maximum value between days 8 and 13 of $366 \pm 22 \mathrm{nmol} \mathrm{L}^{-1}$. At $15^{\circ} \mathrm{C}, \mathrm{DMSP}_{\mathrm{t}}$ concentrations similarly increased after the maximum $\mathrm{Chl} a$ concentrations were reached, but increased faster than at in situ temperature. The maximum $\mathrm{DMSP}_{\mathrm{t}}$ concentrations were $396 \pm 19 \mathrm{nmol} \mathrm{L}^{-1}$ at $15^{\circ} \mathrm{C}$, a value that is not statistically different from the peak values measured at $10^{\circ} \mathrm{C}$ (Fig. $4 \mathrm{a}$; 


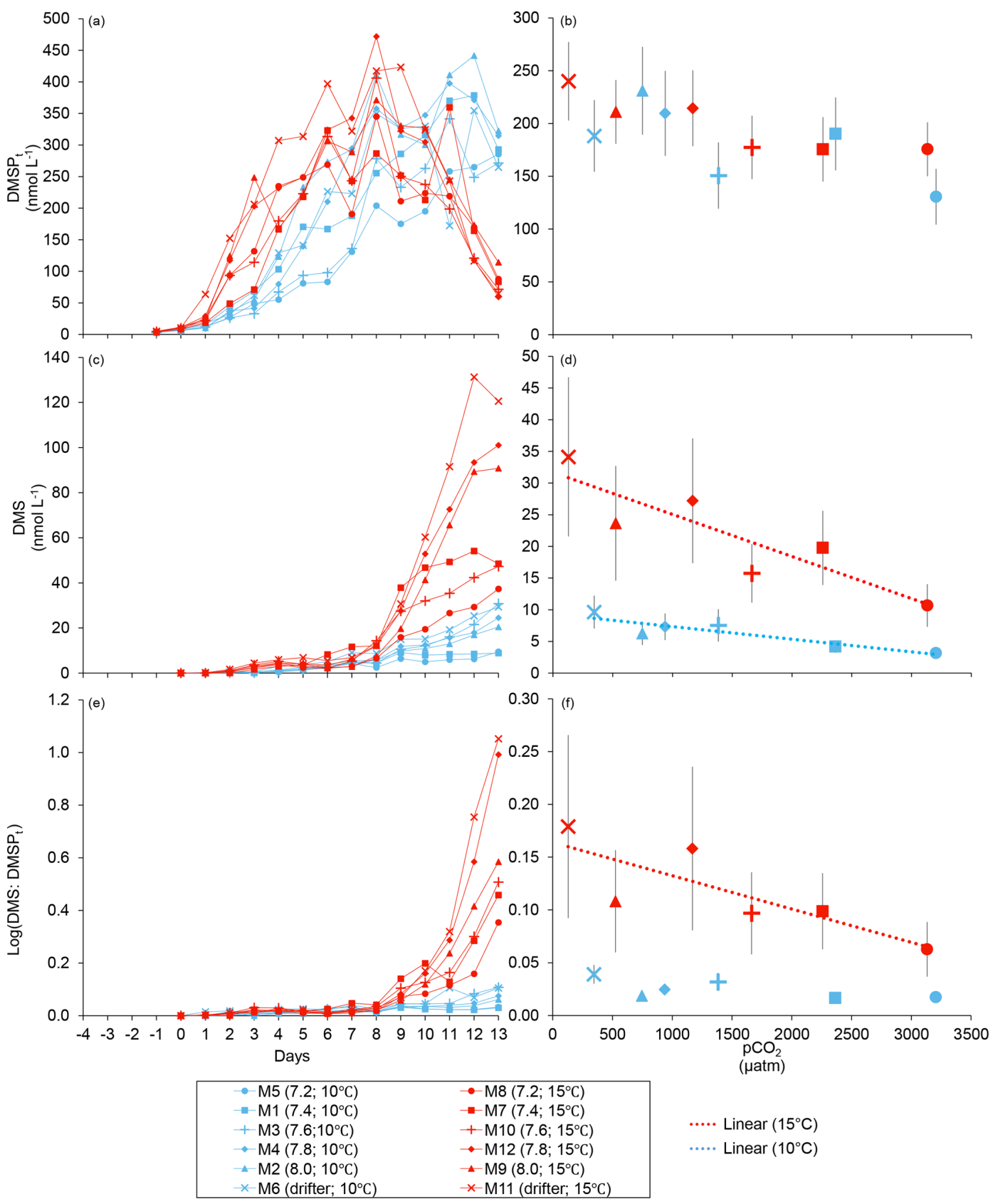

Figure 3. Temporal variations and averages over the course of the experiment (day 0 to day 13) for (a-b) DMSP,$(\mathbf{c}-\mathbf{d})$ DMS, and $(\mathbf{e}-\mathbf{f})$ the natural logarithm of the DMS : DMSP $\mathrm{t}_{\mathrm{t}}$ ratio. For symbol attribution to treatments, see the legend.

Table 2). A greater loss of DMSP took place in the last days of the experiment at $15^{\circ} \mathrm{C}$. By day $13,79 \pm 3 \%$ of the peak DMSP $\mathrm{t}_{\mathrm{t}}$ concentration was lost in the $15^{\circ} \mathrm{C}$ mesocosms, while $19 \pm 4 \%$ of the peak DMSP $_{t}$ concentration was lost at $10^{\circ} \mathrm{C}$. When averaged over the duration of the experiment, the mean $\operatorname{DMSP}_{\mathrm{t}}$ concentrations were not significantly affected by the $p \mathrm{CO}_{2}$ gradient, the temperatures, or the interaction between these two factors (Fig. 3b; Table 1).

Over the 13 days, the $\mathrm{DMSP}_{\mathrm{t}}: \mathrm{Chl} a$ ratio averaged $11.4 \pm$ $0.4 \mathrm{nmol}(\mu \mathrm{g} \mathrm{Chl} a)^{-1}$ at $10^{\circ} \mathrm{C}$ and was not affected by in- creasing $p \mathrm{CO}_{2}$ (Fig. 5; Table 1). Due to the aforementioned mismatch between the peaks in Chl $a$ and $\mathrm{DMSP}_{\mathrm{t}}$, the average $\mathrm{DMSP}_{\mathrm{t}}: \mathrm{Chl} a$ ratios were significantly higher at $15^{\circ} \mathrm{C}$, averaging $19 \pm 1 \mathrm{nmol}(\mu \mathrm{g} \mathrm{Chl} a)^{-1}$ over the experiment (Fig. 5; Table 1). However, we found no significant relationship between $\mathrm{DMSP}_{\mathrm{t}}$ : Chl $a$ and the $p \mathrm{CO}_{2}$ gradient.

Initial DMS concentrations were below the detection limit on day $0\left(<0.9 \mathrm{nmol} \mathrm{L}^{-1}\right)$ and slowly increased during the first 7 days, while most of the build-up took place after day 8 in all treatments (Fig. 3b). The net accumulation of DMS 
Table 2. Results of the generalized least squares models (gls) tests for the effects of temperature, $p \mathrm{CO}_{2}$, and their interaction on the maximum values of the parameters measured during the experiment. Separate analyses with $p \mathrm{CO}_{2}$ as a continuous factor were performed when temperature had a significant effect. Maxima of DMSP $\mathrm{t}_{\mathrm{t}}$ and DMS concentrations are presented with corresponding degrees of freedom (df). Significant results are in bold.

\begin{tabular}{llrrr}
\hline Response variable & Factor & df & $t$-value & $p$-value \\
\hline DMSP $_{\mathrm{t}}\left(\mathrm{nmol} \mathrm{L}^{-1}\right)$ & Temperature & 8 & 0.384 & 0.711 \\
& $p \mathrm{CO}_{2}$ & 8 & -0.713 & 0.496 \\
& $p \mathrm{CO}_{2} \times$ temperature & 8 & 0.300 & 0.772 \\
\hline DMS $\left(\mathrm{nmol} \mathrm{L}^{-1}\right)$ & Temperature & 8 & $\mathbf{6 . 4 0 3}$ & $<\mathbf{0 . 0 0 1}$ \\
& $p \mathrm{CO}_{2}\left(10^{\circ} \mathrm{C}\right)$ & 4 & $\mathbf{- 2 . 8 6 8}$ & $\mathbf{0 . 0 4 6}$ \\
& $p \mathrm{CO}_{2}\left(15^{\circ} \mathrm{C}\right)$ & 4 & $\mathbf{- 4 . 0 6 1}$ & $\mathbf{0 . 0 1 5}$ \\
\hline
\end{tabular}

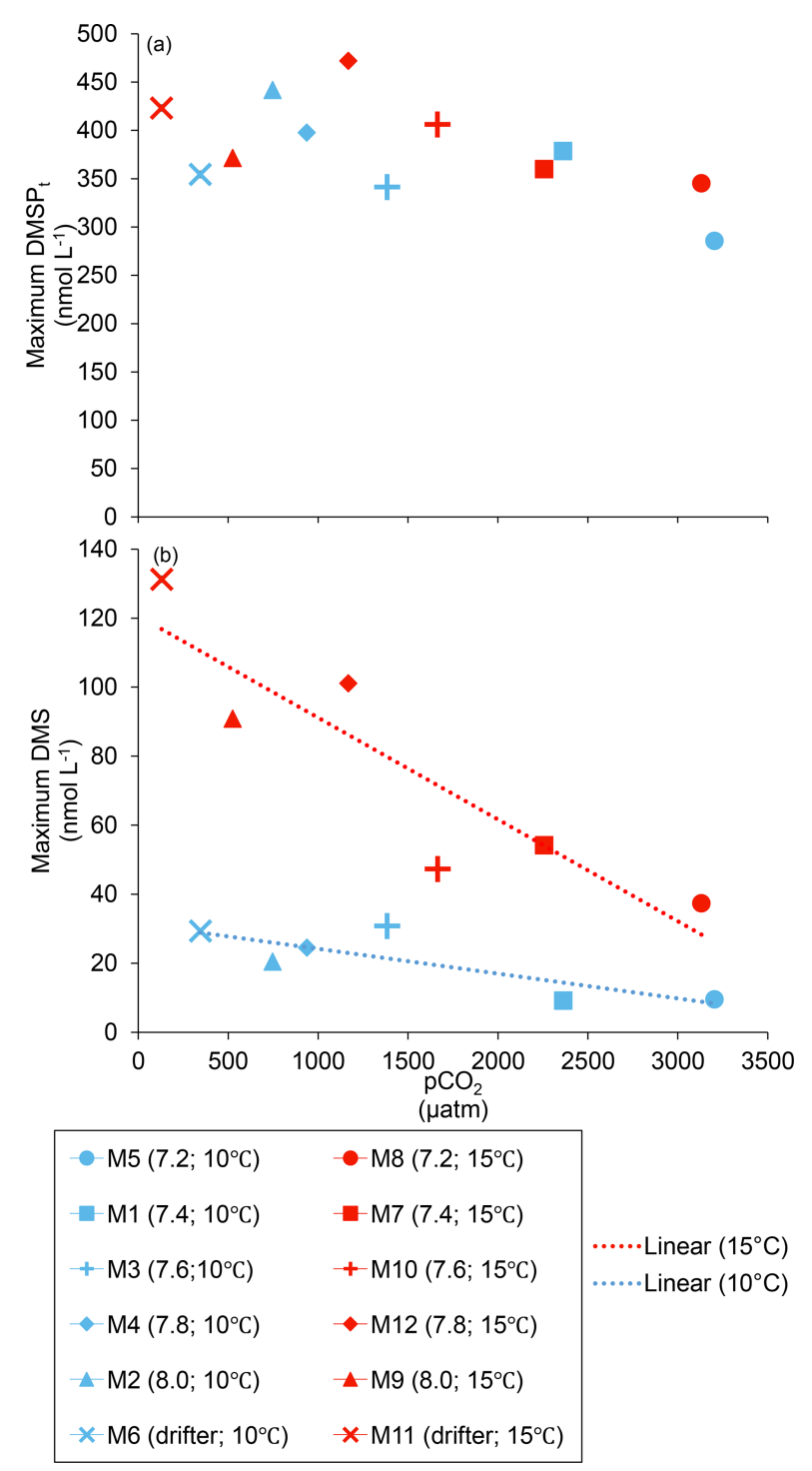

Figure 4. Maximum concentrations reached over the course of the experiment for (a) DMSP $_{t}$ and (b) DMS. For symbol attribution to treatments, see the legend.

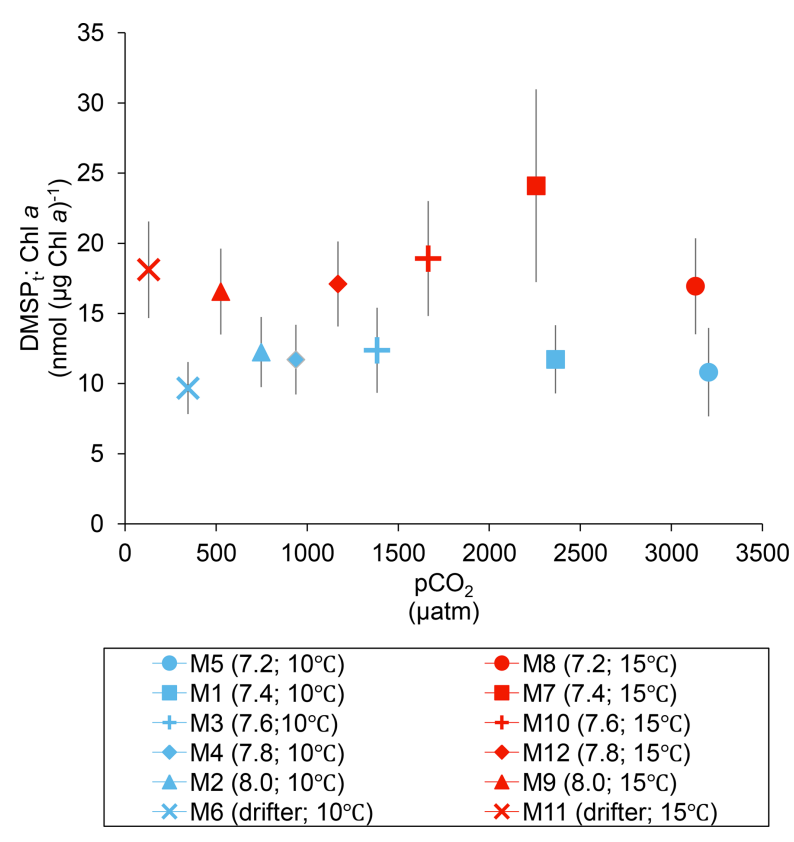

Figure 5. Averages of the DMSP $\mathrm{t}_{\mathrm{t}}$ : Chl $a$ ratio over the course of the experiment (day 0 to day 13). For symbol attribution to treatments, see the legend.

was faster at $15^{\circ} \mathrm{C}$ than at $10^{\circ} \mathrm{C}$, with higher daily DMS concentrations at $15^{\circ} \mathrm{C}$ compared to $10^{\circ} \mathrm{C}$ from day 3 until day 13. At the end of the experiment, DMS concentrations averaged $21 \pm 4 \mathrm{nmol} \mathrm{L}^{-1}$ at $10^{\circ} \mathrm{C}$ and $74 \pm 14 \mathrm{nmol} \mathrm{L}^{-1}$ at $15^{\circ} \mathrm{C}$. Over the full duration of the experiment, we found significant negative effects of increasing $p \mathrm{CO}_{2}$ on mean DMS concentrations at the two temperatures tested (Fig. 3d; Table 1 ). At $10^{\circ} \mathrm{C}$, we measured a $\sim 67 \%$ reduction of mean DMS concentrations from the drifter relative to the most acidified treatment $(\sim 345 \mathrm{ppm}$ vs. $\sim 3200 \mathrm{ppm})$, with values decreasing from $10 \pm 2$ to $3.2 \pm 0.8 \mathrm{nmol} \mathrm{L}^{-1}$. At $15^{\circ} \mathrm{C}$, the mean DMS concentrations decreased by roughly the same percentage $(\sim 69 \%)$ as $p \mathrm{CO}_{2}$ increased from the drifter to the most acidified treatment $(\sim 130 \mathrm{ppm}$ vs. $\sim 3130 \mathrm{ppm})$. Nevertheless, the mean DMS concentrations were higher at 


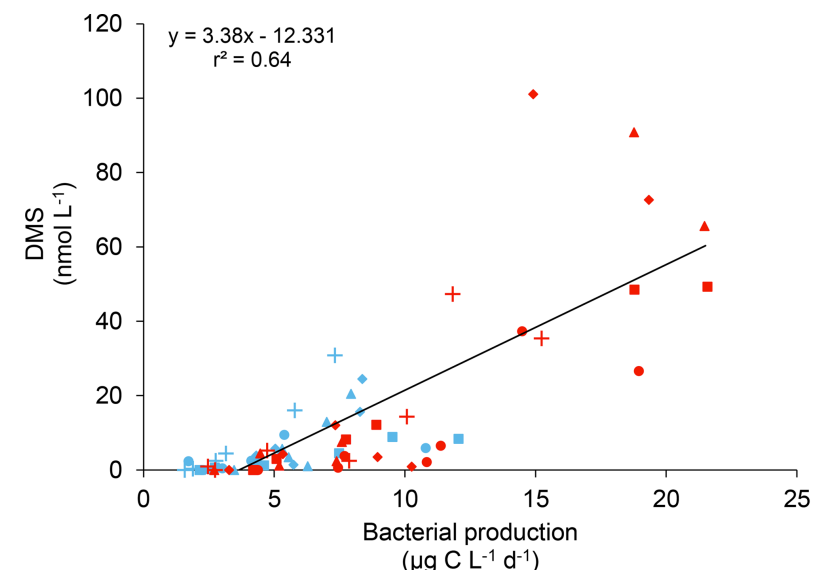

$\left(\mu \mathrm{g} \mathrm{C} \mathrm{L-1} \mathrm{d}^{-1}\right)$

$=\mathrm{M} 1\left(7.4-10^{\circ} \mathrm{C}\right) \quad \triangle \mathrm{M} 2\left(8.0-10^{\circ} \mathrm{C}\right)+\mathrm{M} 3\left(7.6-10^{\circ} \mathrm{C}\right) \bullet \mathrm{M} 4\left(7.8-10^{\circ} \mathrm{C}\right) \quad \mathrm{M} 5\left(7.2-10^{\circ} \mathrm{C}\right)$ $=\mathrm{M} 7\left(7.4-15^{\circ} \mathrm{C}\right) \quad \mathrm{M} 8\left(7.2-15^{\circ} \mathrm{C}\right) \quad \Delta \mathrm{M} 9\left(8.0-15^{\circ} \mathrm{C}\right)+\mathrm{M} 10\left(7.6-15^{\circ} \mathrm{C}\right) \bullet \mathrm{M} 12\left(7.8-15^{\circ} \mathrm{C}\right)$

Figure 6. Linear regression between DMS concentrations and bacterial production during the experiment.

$15^{\circ} \mathrm{C}$, ranging from $34 \pm 13$ to $11 \pm 3 \mathrm{nmol} \mathrm{L}-1$, an average increase of $\sim 240 \%$ compared to the DMS concentrations at $10^{\circ} \mathrm{C}$ (Fig. 3c; Table 1). Similarly, the peak DMS concentrations decreased linearly with increasing $p \mathrm{CO}_{2}$ at both temperatures, and concentrations were always higher at 15 than at $10^{\circ} \mathrm{C}$ for any given $p \mathrm{CO}_{2}$ (Fig. 4 b; Table 2).

The DMS : DMSP $_{t}$ ratio exhibited the same general pattern as the DMS, i.e. low and stable values during the first 8 days, and increasing values between days 8 and 13 (Fig. 3e). The natural logarithm of the DMS : $\mathrm{DMSP}_{\mathrm{t}}$ ratio was not affected by the $p \mathrm{CO}_{2}$ gradient at $10^{\circ} \mathrm{C}$ when averaged over the 13-day experiment, but a significant decrease in the DMS : $\mathrm{DMSP}_{\mathrm{t}}$ ratios was observed with increasing $p \mathrm{CO}_{2}$ at 15 compared to $10^{\circ} \mathrm{C}$ (Fig. 3f; Table 1). Moreover, there was a significant positive correlation between bacterial production and DMS concentrations, as $64 \%$ of the variability of DMS concentrations is explained by variations in bacterial production $\left(r^{2}=0.64, p<0.001, n=70\right.$; Fig. 6$)$.

\section{Discussion}

\subsection{General characteristics}

As far as we know, this study is the first full factorial mesocosm experiment where all $p \mathrm{CO}_{2}$ treatments $\left(\mathrm{pH}_{\mathrm{T}}\right.$ from 8.0 to 7.2) were replicated at two different temperatures (in situ and $+5{ }^{\circ} \mathrm{C}$ ), to assess the impact of ocean acidification and warming on the dynamics of DMSP and DMS concentrations during a phytoplankton bloom. A diatom bloom dominated by Skeletonema costatum developed in all mesocosms, regardless of the treatments. This chain-forming centric diatom is a cosmopolitan species in coastal and estuarine systems and a frequent bloomer in the Lower St. Lawrence Estuary (LSLE) (Kim et al., 2004; Starr et al., 2004; Annane et al., 2015). The 13 days where treatments were applied allowed us to capture the development and declining phases of the bloom. The impacts of the treatments on the dynamics of the bloom during these two phases are described in greater detail in Bénard et al. (2018a). Briefly, the acidification had no detectable effect on the development rate of the diatom bloom and on the maximum $\mathrm{Chl} a$ concentrations reached. However, increasing the water temperature by $5^{\circ} \mathrm{C}$ increased the growth rate of the diatoms, shortening the development phase of the bloom, from $4-7$ days at $10^{\circ} \mathrm{C}$ to $1-4$ days at $15^{\circ} \mathrm{C}$. However, these changes in the bloom timing did not alter the overall primary production throughout the experiment. Hereafter, we discuss how increasing $p \mathrm{CO}_{2}$ (lowering the $\mathrm{pH}$ ) affected DMSP and DMS concentrations and how a $5^{\circ} \mathrm{C}$ increase in temperature altered the impacts of the $p \mathrm{CO}_{2}$ gradient during the experiment.

\subsection{DMSP dynamics}

The buildup of the phytoplankton biomass during the bloom development was coupled with a rapid increase in $\mathrm{DMSP}_{t}$ concentrations (Fig. 3a). Assuming that $S$. costatum was responsible for most of the DMSP production, our results indicate a low sensitivity of the DMSP synthesis pathway to acidification in this species. The net accumulation of DMSP persisted several days after the peaks in $\mathrm{Chl} a$, indicating a decoupling between DMSP synthesis, algal growth and nitrogen metabolism (Bénard et al., 2018a).

\subsubsection{Effects of acidification on DMSP}

At in situ temperature, the averaged $\mathrm{DMSP}_{\mathrm{t}}$ concentrations were not affected by the increase in $p \mathrm{CO}_{2}$ (Fig. 3b; Table 1). The lack of significant changes in the $\mathrm{DMSP}_{\mathrm{t}}$ : Chl $a$ ratio as a function of the $p \mathrm{CO}_{2}$ gradient also supports this conclusion (Fig. 5; Table 1). This result is consistent with those of previous studies that showed a relatively weak effect of an increase in $p \mathrm{CO}_{2}$ on DMSP concentrations (Vogt et al., 2008; Lee et al., 2009; Avgoustidi et al., 2012; Archer et al., 2013; Webb et al., 2015). Furthermore, much like the patterns observed at $10^{\circ} \mathrm{C}$, there was no relationship between the concentrations of DMSP $\mathrm{t}_{\mathrm{t}}$ and the $p \mathrm{CO}_{2}$ gradient observable at $15^{\circ} \mathrm{C}$ (Table 1).

\subsubsection{Effects of warming on DMSP}

In contrast to the absence of effects of acidification on DMSP, warming has been previously shown to affect DMSP concentrations in nature. Results from shipboard incubation experiments conducted in the North Atlantic have revealed an increase in particulate DMSP $\left(\mathrm{DMSP}_{\mathrm{p}}\right)$ concentrations due to a $4{ }^{\circ} \mathrm{C}$ warming (Lee et al., 2009). During this last study, the higher DMSP $_{p}$ concentrations were attributed to a temperature-induced shift in community structure toward species with higher cellular DMSP content. During our study, the $p \mathrm{CO}_{2}$ and temperature treatments did not alter the struc- 
ture of the community (Bénard et al., 2018a). Most of the DMSP synthesis was likely linked to the numerically dominant diatoms, as all other algal groups identified contributed to less than $10 \%$ of the total algal abundance (see Fig. 6 in Bénard et al., 2018a). Our results thus suggest that DMSP synthesis by $S$. costatum during the nitrate-replete growth phase was not significantly affected by warming. Rather, it is the accelerated growth rate of $S$. costatum that promoted the concurrent accumulation of biomass and $\mathrm{DMSP}_{t}$, while the higher DMSP ${ }_{\mathrm{t}}: \mathrm{Chl} a$ ratio observable at $15^{\circ} \mathrm{C}$ may be explained by the faster degradation of cells under warming. Several empty frustules were found during the last days of the experiment at $15^{\circ} \mathrm{C}$, suggesting a loss of integrity of the cells and potential increase in the release of intracellular dissolved organic matter, including DMSP. However, the absence of dissolved DMSP measurements prevents the verification of this suggestion. The increase in the abundance of bacteria and in bacterial production (Fig. 2c, e) during that period also suggest that more dissolved organic matter was produced during the decline of the bloom, as previously reported (Engel et al., 2004a, b). During our experiment, transparent exopolymer particles (TEP) concentrations increased during this period (Gaaloul, 2017), adding to the evidence for heightened DOM production by the decaying bloom, with a potential increase in DMSP metabolization by heterotrophic bacteria under warming.

\subsection{DMS dynamics}

DMS concentrations remained very low during the development phase of the bloom (day 8) and increased in the latter days of the experiment. Most of the DMS accumulation in the mesocosms took place between days 8 and 13 and likely originated from DMSP that may have been released during cell lysis (Kwint and Kramer, 1995) or upon zooplankton grazing (Cantin et al., 1996). Unbalanced growth and photosynthesis of algal cells under nitrogen deficiency during that period may also be responsible for a greater production and active exudation of DMSP (Stefels, 2000; Kettles et al., 2014).

\subsubsection{Effects of acidification on DMS}

At in situ temperature, we observed a significant linear decrease in DMS concentrations (both averaged over the full duration of the experiment and peak concentrations) with increasing $p \mathrm{CO}_{2}$ (Figs. 3c, 4b; Tables 1 and 2). A few studies have shown a neutral or positive effect of increasing $p \mathrm{CO}_{2}$ on DMS concentrations, stemming from altered phytoplankton taxonomy, microzooplankton grazing, or diverging bacterial activity promoting DMS production (Vogt et al., 2008; Kim et al., 2010; Hopkins and Archer, 2014). However, the majority of studies have shown a decreasing trend of DMS concentrations with increasing $p \mathrm{CO}_{2}$ similar to our results (Hopkins et al., 2010; Archer et al., 2013; Park et al., 2014; Webb et al.,
2015, 2016). In these studies, the $p \mathrm{CO}_{2}$-induced decreases in DMS were generally attributed to changes in the microbial community speciation and structure, or to microzooplankton grazing, although decreases in bacterial DMSP-to-DMS conversion or increases in DMS consumption have also been suggested (Archer et al., 2013; Hussherr et al., 2017). During our study, the decrease in DMS concentrations with increasing $p \mathrm{CO}_{2}$ cannot be directly attributed to a decrease in DMSP $_{\mathrm{t}}$ since this pool was not affected by the $p \mathrm{CO}_{2}$ gradient (Figs. 3b, 4a; Tables 1 and 2). In Park et al. (2014), the increase in $p \mathrm{CO}_{2}$ led to the reduction in the abundance of Alexandrium spp., an active DMSP and DMSP-lyase producer, and a concomitant reduction of the associated microzooplankton grazing. As Alexandrium spp. was less numerous, the associated attenuation of microzooplankton grazing resulted in a reduction of the mixing of DMSP and DMSPlyase, leading to less DMSP-to-DMS conversion. Given the strong contribution of $S$. costatum to the bloom, a species with no reported DMSP-lyase, it can be assumed that most, if not all, of the DMS produced was driven by bacterial processes following DMSP release by the diatoms. Thus, the decrease in DMS concentrations in our study could have been the result of altered bacterial mediation, through either reduced bacterial production of DMS or heightened bacterial consumption of DMS. Whereas a reduction in bacterial uptake of DMSP is unlikely, given that the bacterial abundance and production were unaffected by the $p \mathrm{CO}_{2}$ gradient (Table 1), the observed decrease in DMS concentrations could imply that at higher $p \mathrm{CO}_{2}$ the bacterial yields of DMS are abated. The relative proportion of DMSP consumed by bacteria and further cleaved into DMS is closely tied to bacterial demand in carbon and sulfur as well as to the availability of DMSP relative to other sources of reduced sulfur in the environment (Levasseur et al., 1996; Kiene et al., 2000; Pinhassi et al., 2005). The absence of a significant $p \mathrm{CO}_{2}$ effect on the concentrations of DMSP during this study may be interpreted as a $p \mathrm{CO}_{2}$-related alteration of the microbially mediated fate of consumed DMSP. Unfortunately, in the absence of detailed ${ }^{35} \mathrm{~S}_{-} \mathrm{DMSP}_{\mathrm{d}}$ bioassays, it is impossible to confirm the outcome of the DMSP metabolic pathways including the DMSP-to-DMS conversion efficiency in relation to the $p \mathrm{CO}_{2}$ gradient. A few studies (Grossart et al., 2006; Engel et al., 2014; Webb et al., 2015) have reported enhanced bacterial abundance and production at high $p \mathrm{CO}_{2}$, especially for attached bacteria as opposed to free-living bacteria (Grossart et al., 2006). However, regardless of the temperature treatment, neither the abundance nor the activity of bacteria seemed to be significantly impacted by $p \mathrm{CO}_{2}$ in this study. A $p \mathrm{CO}_{2}$-induced increase in bacterial DMS turnover could also explain the decrease in DMS concentrations, but several studies suggest that bacterial DMS consumption in natural systems is often tightly coupled to DMS production itself (Simó, 2001, 2004). Furthermore, while one laboratory study reported that non-limiting supplies of DMS may be used as a substrate by several members of Bacteroidetes 
(Green et al., 2011), another study showed that only a subset of the natural microbial population may turn over naturally occurring levels of DMS (Vila-Costa et al., 2006b). Nevertheless, the sensitivity of these DMS-consuming bacteria to decreasing $\mathrm{pH}$ remains unknown. Likewise, whereas we cannot exclude a potential impact of $p \mathrm{CO}_{2}$ on DMS turnover via bacterioplankton, it is plausible that the $p \mathrm{CO}_{2}$ gradient may have affected a widespread physiological pathway among bacteria, specifically, the metabolic breakdown of DMSP.

\subsubsection{Effects of warming on DMS}

A warming by $5^{\circ} \mathrm{C}$ increased DMS concentrations at all $p \mathrm{CO}_{2}$ tested, resulting in an offset of the negative $p \mathrm{CO}_{2}$ impact when compared to the in situ temperature. This result differs from the observation of Kim et al. (2010) and Park et al. (2014) in two ways. First, our results show an increase in DMS concentrations in the warmer treatment, while the two previous studies reported a decrease. Second, our results confirm that a temperature effect may be measured over a large range of $p \mathrm{CO}_{2}$. It is noteworthy that the increase in DMS concentrations at the two temperatures tested varied from $110 \%$ at $\mathrm{pH} 8.0$ up to $370 \%$ at $\mathrm{pH} 7.4$. This highlights the scaling of the temperature effect over an extensive range of $p \mathrm{CO}_{2}$ and the importance of simultaneously studying the impact of these two factors on DMS production. As observed at $10^{\circ} \mathrm{C}$, both the average and the peak DMS concentrations decreased linearly as $p \mathrm{CO}_{2}$ increased in the warm treatment (Figs. 3d, 4b; Tables 1 and 2). Nevertheless, the $p \mathrm{CO}_{2}$-induced decrease in DMS concentrations at $15^{\circ} \mathrm{C}$ cannot be directly attributed to a decrease in $\mathrm{DMSP}_{\mathrm{t}}$ concentrations given that an increase in $p \mathrm{CO}_{2}$ had no discernable effect on $\mathrm{DMSP}_{\mathrm{t}}$ concentrations. In contrast to our observations at the in situ temperature, where $\mathrm{DMSP}_{\mathrm{t}}$ continued to increase until day $12, \mathrm{DMSP}_{\mathrm{t}}$ concentrations at $15^{\circ} \mathrm{C}$ typically decreased from day 8 onward (Fig. 3a). This loss in DMSP $\mathrm{t}_{\mathrm{t}}$ suggests that microbial consumption of DMSP exceeded DMSP algal synthesis. In light of the dominance of $S$. costatum, a phytoplankton taxon not known to exhibit DMSP-lyase, the bulk of microbial DMSP mediation was likely associated with heterotrophic bacteria. In support of this hypothesis, the bacterial production was $\sim 2$ times higher at 15 than at $10^{\circ} \mathrm{C}$ between days 8 and 13 (19 $\pm 1 \mu \mathrm{g} \mathrm{CL}^{-1} \mathrm{~d}^{-1}$ vs. $9.3 \pm 0.9 \mu \mathrm{g} \mathrm{CL}^{-1} \mathrm{~d}^{-1}$ ) (Fig. 2), and we observed a significant correlation between the quantity of DMSP $\mathrm{D}_{\mathrm{t}}$ lost between the day of the maximum DMSP concentrations and day 13, and the quantity of DMS produced during the same period (coefficient of determination, $\left.r^{2}=0.60, p<0.01, n=11\right)$. Assuming that all the DMSP lost was transformed into DMS by bacteria, we calculated that DMS yields could have varied by $0.5 \%$ to $32 \%$ across the $p \mathrm{CO}_{2}$ gradient $($ mean $=13 \pm 11 \%$ ). These very rough estimates of DMS yields are likely at the lower end since measured DMS concentrations also reflect losses of DMS through photo-oxidation and bacterial consumption. Never- theless, we cannot exclude the possibility of some passive uptake of DMSP by the picocyanobacterial population in the mesocosms, although this pathway is not considered to be significant in natural systems (Malmstrom et al., 2005; VilaCosta et al., 2006a) and does not lead to the production of DMS. Moreover, our estimates do not account for the possible DMSP assimilation by grazers, reducing the $\mathrm{DMSP}_{\mathrm{d}}$ available for bacteria, and would lead to an increase in DMS yields. Our "minimum community" DMS yield estimates agree with an expected range of microbial DMS yields in natural environments, from $2 \%$ to $45 \%$ (see review table in $\mathrm{Li}$ zotte et al., 2017). These gross but realistic estimates of heterotrophic bacterial DMSP-to-DMS conversions could explain the bulk of the DMS present in our study, a hypothesis also supported by the strong positive correlation $\left(r^{2}=0.64\right.$, $p<0.001, n=70$; Fig. 6) between overall DMS concentrations and bacterial production. Combined, these findings reinforce the idea that bacterial metabolism, rather than bacterial stocks, may significantly affect the fate of DMSP (Malmstrom et al., 2004a, b, 2005; Vila et al., 2004; Vila-Costa et al., 2007; Royer et al., 2010; Lizotte et al., 2017). Consequently, drivers of environmental change, such as temperature and $\mathrm{pH}$, could alter bacterial activity and strongly impact the concentrations of DMS by controlling the rates of production and loss of DMS by bacteria. Specific measurements of bacterial DMSP uptake and DMS yields using ${ }^{35} \mathrm{~S}$ DMSP $_{\mathrm{d}}$ should be conducted to assess the impacts of $p \mathrm{CO}_{2}$ and temperature on the microbial fate of DMSP.

\subsection{Limitations}

During our study, the $p \mathrm{CO}_{2}$ changes were applied abruptly, over a day, from in situ values to $p \mathrm{CO}_{2}$ levels exceeding the most pessimistic $p \mathrm{CO}_{2}$ scenarios for the end of the century. Compared to our manipulation, ocean acidification will proceed at a much slower rate, potentially allowing species to adapt and evolve to these changing conditions (Stillman and Paganini, 2015; Schlüter et al., 2016). However, in the LSLE, the upwelling of low oxygenated waters can rapidly reduce the $\mathrm{pH}_{\mathrm{T}}$ to $\sim 7.62$, or even lower with contributions of low $\mathrm{pH}_{\mathrm{T}}$ (7.12) freshwaters from the Saguenay River during the spring freshet (Mucci et al., 2017). Thus, the swift and extensive $p \mathrm{CO}_{2}$ range deployed in our experiment may seem improbable for the open ocean on the short term, but may not be inconceivable for this coastal region. However, the warming of $5^{\circ} \mathrm{C}$ used in this mesocosm study possibly exceeds the upper limit of temperature increase for the end of the century in this region. In the adjacent Gulf of St. Lawrence (GSL), surface water temperature (SST) correlates strongly with air temperature, allowing the estimation of past SST. This relationship showed that SST has increased in the GSL by $0.9^{\circ} \mathrm{C}$ per century since 1873 (Galbraith et al., 2012), although additional positive anomalies of $0.25-0.75^{\circ} \mathrm{C}$ per decade have been shown between 1985 and 2013 (Galbraith et al., 2016). In the LSLE, the highest temperatures occur 
at the end of summer/early fall, and gradually dissipate by heating the subjacent cold intermediate layer through vertical mixing (Cyr et al., 2011). The extent of the projected warming in the LSLE is recondite, but will likely result from the multifaceted interactions between heat transfer from the air and physical factors controlling the water masses.

The results from our study could also be influenced by the absence of macrograzers in the mesocosms. An additional grazing pressure could limit the growth of the blooming species, reducing the amount of DMSP produced, or could increase the release of $\mathrm{DMSP}_{\mathrm{d}}$ through sloppy feeding after the initial bloom (Lee et al., 2003). It is unclear how an increase in grazing pressure would have impacted the concentrations of DMS in our experiment. On the one hand, increased predation could have limited the net accumulation of $\mathrm{DMSP}_{\mathrm{p}}$, with a possible reduction in DMS production. On the other hand, increased grazing could have favored the release of DMSP $_{\mathrm{p}}$ as DMSPd, thus increasing the availability of this substrate for microbial uptake, mediation, and possible conversion into DMS. Despite the absence of reported changes in community composition in our study, many OA mesocosm experiments have described changes in DMS concentrations associated with shifts in community structure in the past (Vogt et al., 2008; Hopkins et al., 2010; Kim et al., 2010; Park et al., 2014; Webb et al., 2015). Nonetheless, our results align with those of other OA studies (Archer et al., 2013; Hussherr et al., 2017), suggesting that the mediation of heterotrophic bacteria plays a major role in DMS cycling in the absence of reported phytoplanktonic DMSP-lyase, such as in a diatom-dominated bloom in the LSLE.

\section{Conclusions}

The objective of this study was to quantify the combined impact of increases in $p \mathrm{CO}_{2}$ and temperature on the dynamics of DMS during a fall diatom bloom in the St. Lawrence Estuary. Our mesocosm experiment allowed us to capture the development and declining phases of a bloom strongly dominated by the diatom Skeletonema costatum and the related changes in bacterial abundance and production. As expected, warming accelerated the development of the bloom, but also its decline. Both $\mathrm{DMSP}_{\mathrm{t}}$ and DMS concentrations increased during the development phase of the bloom, but their peak concentrations were reached as the bloom was declining. Increasing $p \mathrm{CO}_{2}$ had no discernable effect on the total amount of DMSP $_{t}$ produced at both temperatures tested. In contrast, increasing the $p \mathrm{CO}_{2}$ to the value forecasted for the end of this century resulted in a linear decrease in DMS concentrations by $33 \%$ and by as much as $69 \%$ over the full $p \mathrm{CO}_{2}$ gradient tested. These results are consistent with previous reports that acidification has a greater impact on the processes that control the conversion of DMSP to DMS than on the production of DMSP itself. The $p \mathrm{CO}_{2}$-induced decrease in DMS concentrations observed in this study adds to the bulk of previous studies reporting a similar trend. In diatomdominated systems, such as the one under study in this experiment, heterotrophic processes underlying DMS production seem to be most sensitive to modifications in $p \mathrm{CO}_{2}$. Whereas predatory grazing and its associated impacts on DMS production cannot be ruled out entirely, the decreases in DMS concentrations in response to heightened $p \mathrm{CO}_{2}$ are likely related to reductions in bacterial-mediated DMS production, a hypothesis partly supported by the significant positive correlations found between DMS concentrations and bacterial production. Whereas the DMS concentrations decreased significantly with increasing $p \mathrm{CO}_{2}$ at both 10 and $15^{\circ} \mathrm{C}$, warming the mesocosms by $5^{\circ} \mathrm{C}$ translated into a positive offset in concentrations of DMS over the whole range of $p \mathrm{CO}_{2}$ tested. Higher DMSP release and increased bacterial productivity in the warm treatment partially explain the stimulating effect of temperature on DMS net production. Overall, results from this full factorial mesocosm experiment suggest that warming could mitigate the expected reduction in DMS production due to ocean acidification, even increasing the net DMS production with the potential to curtail radiative forcing. Further studies should focus on the relationship between bacterial conversion of DMSP to DMS and $p \mathrm{CO}_{2}$, to mechanistically verify the suggested cause of the DMS reduction observed in this experiment. Moreover, an extended range of temperature should also be considered for future multiple stressors experiment as warming had, more often than not, a stronger effect on the community than acidification.

Data availability. The data are freely accessible via https://doi.org/ 10.1594/PANGAEA.886887 (Bénard et al., 2018b) or can be obtained by contacting the author (robin.benard.1@ulaval.ca).

Author contributions. RB was responsible for the experimental design elaboration, data sampling and processing, and writing of this article. Several co-authors supplied specific data included in this article, and all the co-authors contributed to this final version of the article.

Competing interests. The authors declare that they have no conflict of interest.

Acknowledgements. The authors wish to thank Station AquicoleISMER, particularly Nathalie Morin and her staff, for their support during the mesocosm experiment. We also wish to acknowledge Gilles Desmeules, Bruno Cayouette, Sylvain Blondeau, Claire Lix, Rachel Hussherr, Liliane St-Amand, Marjolaine Blais, Armelle Galine Simo Matchim, and Marie-Amélie Blais for their invaluable help over the duration of the experiment. This study was funded by a team grant from the Fonds de recherche du Québec - Nature et technologies (FRQNT-Équipe-165335), the Canada Foundation for Innovation, the Canada Research Chair on Ocean 
Biogeochemistry and Climate, Fisheries and Oceans Canada, and the Major International Joint Research Project of the National Natural Science Foundation of China (grant no. 41320104008). This is a contribution to the research program of Québec-Océan.

Edited by: Koji Suzuki

Reviewed by: three anonymous referees

\section{References}

Andreae, M. O.: Ocean-atmosphere interactions in the global biogeochemical sulfur cycle, Mar. Chem., 30, 1-3, 1990.

Andreae, M. O. and Crutzen, P. J.: Atmospheric aerosols: biogeochemical sources and role in atmospheric chemistry, Science, 276, 1052-1058, https://doi.org/10.1126/science.276.5315.1052, 1997.

Annane, S., St-Amand, L., Starr, M., Pelletier, E., and Ferreyra, G. A.: Contribution of transparent exopolymeric particles (TEP) to estuarine particulate organic carbon pool, Mar. Ecol.-Prog. Ser., 529, 17-34, https://doi.org/10.3354/meps11294, 2015.

Archer, S. D., Kimmance, S. A., Stephens, J. A., Hopkins, F. E., Bellerby, R. G. J., Schulz, K. G., Piontek, J., and Engel, A.: Contrasting responses of DMS and DMSP to ocean acidification in Arctic waters, Biogeosciences, 10, 1893-1908, https://doi.org/10.5194/bg-10-1893-2013, 2013.

Asher, E. C., Dacey, J. W. H., Mills, M. M., Arrigo, K. R., and Tortell, P. D. High concentrations and turnover rates of DMS, DMSP and DMSO in Antarctic sea ice, Geophys. Res. Lett., 38, 1-5, https://doi.org/10.1029/2011GL049712, 2011.

Avgoustidi, V., Nightingale, P. D., Joint, I., Steinke, M., Turner, S. M., Hopkins, F. E., and Liss, P. S.: Decreased marine dimethyl sulfide production under elevated $\mathrm{CO}_{2}$ levels in mesocosm and in vitro studies, Environ. Chem., 9, 399, https://doi.org/10.1071/EN11125, 2012.

Barnard, W. R., Andreae, M. O., Watkins, W. E., Bingemer, H., and Georgii, H. W.: The flux of dimethylsulfide from the oceans to the atmosphere, J. Geophys. Res., 87, 8787-8793, 1982.

Bates, T. S., Lamb, B. K., Guenther, A., Dignon, J., and Stoiber, R. E.: Sulfur emissions to the atmosphere from natural sources, J. Atmos. Chem., 14, 315-337, https://doi.org/10.1007/BF00115242, 1992.

Bell, R. T.: Estimating production of heterotrophic bacterioplankton via incorporation of tritiated thymidine, in: Handbook of methods in aquatic microbial ecology, edited by: Kemp, P. F., Sherr, B. F., Sherr, E. B., and Cole, J., Lewis Publisher, Boca Raton, 495-503, 1993.

Belzile, C., Brugel, S., Nozais, C., Gratton, Y., and Demers, S.: Variations of the abundance and nucleic acid content of heterotrophic bacteria in Beaufort Shelf waters during winter and spring, J. Marine Syst., 74, 946-956, https://doi.org/10.1016/j.jmarsys.2007.12.010, 2008.

Bénard, R., Levasseur, M., Scarratt, M., Blais, M.-A., Mucci, A., Ferreyra, G., Starr, M., Gosselin, M., Tremblay, J.-É., and Lizotte, M.: Experimental assessment of the sensitivity of an estuarine phytoplankton fall bloom to acidification and warming, Biogeosciences, 15, 4883-4904, https://doi.org/10.5194/bg-154883-2018, 2018a.
Bénard, R., Levasseur, M., Scarratt, M., Blais, M.-A., Mucci, A., Ferreyra, G. A., Starr, M., Gosselin, M., Tremblay, J.-É., Lizotte, M., Michaud, S., and Yang, G.: Experimental assessment of the St. Lawrence Estuary phytoplankton fall bloom sensitivity and DMS concentrations to acidification and warming, PANGAEA, https://doi.org/10.1594/PANGAEA.886887, 2018b.

Boyd, P. W., Lennartz, S. T., Glover, D. M., and Doney, S. C.: Biological ramifications of climate-change-mediated oceanic multi-stressors, Nat. Clim. Change, 5, 71-79, https://doi.org/10.1038/nclimate2441, 2015.

Boyd, P. W., Collins, S., Dupont, S., Fabricius, K., Gattuso, J.-P., Havenhand, J., Hutchins, D. A., Riebesell, U., Rintoul, M. S., Vichi, M., Biswas, H., Ciotti, A., Gao, K., Gehlen, M., Hurd, C. L., Kurihara, H., McGraw, C. M., Navarro, J. M., Nilsson, G. E., Passow, U., and Pörtner, H.-O.: Experimental strategies to assess the biological ramifications of multiple drivers of global ocean change-A review, Glob. Change Biol., 24, 2239-2261, https://doi.org/10.1111/gcb.14102, 2018.

Brimblecombe, P. and Shooter, D.: Photo-oxidation of dimethylsulphide in aqueous solution, Mar. Chem., 19, 343-353, 1986.

Byrne, R. H.: Standardization of Standard Buffers by Visible Spectrometry, Anal. Chem, 59, 1479-1481, https://doi.org/10.1021/ac00137a025, 1987.

Cai, W. J. and Wang, Y.: The chemistry, fluxes, and sources of carbon dioxide in the estuarine waters of the Satilla and Altamaha Rivers, Georgia, Limnol. Oceanogr., 43, 657-668, https://doi.org/10.4319/lo.1998.43.4.0657, 1998.

Caldeira, K. and Wickett, M. E.: Ocean model predictions of chemistry changes from carbon dioxide emissions to the atmosphere and ocean, J. Geophys. Res., 110, 1-12, https://doi.org/10.1029/2004JC002671, 2005.

Cantin, G., Levasseur, M., Gosselin, M., and Michaud, S.: Role of zooplankton in the mesoscale distribution of surface dimethylsulfide concentrations in the Gulf of St. Lawrence, Canada, Mar. Ecol.-Prog. Ser., 141, 103-117, 1996.

Cantoni, G. L. and Anderson, D.: Enzymatic cleavage of dimethylpropiothetin by Polysiphonia Lanosa, J. Biol. Chem., 222, 171177, 1956.

Carslaw, K. S., Boucher, O., Spracklen, D. V., Mann, G. W., Rae, J. G. L., Woodward, S., and Kulmala, M.: A review of natural aerosol interactions and feedbacks within the Earth system, Atmos. Chem. Phys., 10, 1701-1737, https://doi.org/10.5194/acp10-1701-2010, 2010.

Charlson, R., Lovelock, J., Andreae, M., and Warren, S.: Oceanic phytoplankton, atmospheric sulphur, cloud albedo and climate, Nature, 326, 656-661, 1987.

Clayton, T. D. and Byrne, R. H.: Spectrophotometric seawater $\mathrm{pH}$ measurements: total hydrogen ion concentration scale calibration of m-cresol purple and at-sea results, Deep-Sea Res. Pt. I, 40, 2115-2129, https://doi.org/10.1016/0967-0637(93)90048-8, 1993.

Cyr, F., Bourgault, D., and Galbraith, P. S.: Interior versus boundary mixing of a cold intermediate layer, J. Geophys. Res.-Ocean. 116, 1-12, https://doi.org/10.1029/2011JC007359, 2011.

Dacey, J. W. H. and Wakeham, S. G.: Oceanic dimethylsulfide: production during zooplankton grazing, Science, 233, 1314-1316, 1986.

Dickson, A. G.: Standard potential of the reaction: $\mathrm{AgCl}(\mathrm{s})+12 \mathrm{H}_{2}(\mathrm{~g})=\mathrm{Ag}(\mathrm{s})+\mathrm{HCl}(\mathrm{aq})$ and the standard 
acidity constant of the ion $\mathrm{HSO}_{4}^{-}$in synthetic sea water from 273.15 to $318.15 \mathrm{~K}$, J. Chem. Thermodyn., 22, 113-127, https://doi.org/10.1016/0021-9614(90)90074-Z, 1990.

Doney, S. C., Fabry, V. J., Feely, R. A., and Kleypas, J. A.: Ocean acidification: The other $\mathrm{CO}_{2}$ problem, Annu. Rev. Mar. Sci., 1, 169-192, https://doi.org/10.1146/annurev.marine.010908.163834, 2009.

Engel, A., Delille, B., Jacquet, S., Riebesell, U., Rochelle-Newall, E., Terbrüggen, A., and Zondervan, I.: Transparent exopolymer particles and dissolved organic carbon production by Emiliania huxleyi exposed to different $\mathrm{CO}_{2}$ concentrations: A mesocosm experiment, Aquat. Microb. Ecol., 34, 93-104, https://doi.org/10.3354/ame034093, 2004a.

Engel, A., Thoms, S., Riebesell, U., Rochelle-Newall, E., and Zondervan, I.: Polysaccharide aggregation as a potential sink of marine dissolved organic carbon, Nature, 428, 929-932, https://doi.org/10.1038/nature02453, 2004b.

Engel, A., Piontek, J., Grossart, H.-P., Riebesell, U., Schulz, K. G., and Sperling, M.: Impact of $\mathrm{CO}_{2}$ enrichment on organic matter dynamics during nutrient induced coastal phytoplankton blooms, J. Plankton Res., 36, 641-657, https://doi.org/10.1093/plankt/fbt125, 2014.

Feely, R. A., Doney, S. C., and Cooley, S. R.: Ocean Acidification: Present Conditions and Future Changes in a High- $\mathrm{CO}_{2}$ World, Oceanography, 22, 36-47, https://doi.org/10.5670/oceanog.2009.95, 2009.

Fuhrman, J. A. and Azam, F.: Bacterioplankton secondary production estimates for coastal waters of British Columbia, Antarctica, and California, Appl. Environ. Microb., 39, 1085-1095, 1980.

Fuhrman, J. A. and Azam, F.: Thymidine incorporation as a measure of heterotrophic bacterioplankton production in marine surface waters: Evaluation and field results, Mar. Biol., 66, 109-120, https://doi.org/10.1007/BF00397184, 1982.

Gaaloul, H.: Effets du changement global sur les particules exopolymériques transparentes au sein de l'estuaire maritime du Saint-Laurent, MSc thesis, Université du Québec à Rimouski, Canada, 133 pp., 2017.

Galbraith, P. S., Chassé, J., Gilbert, D., Larouche, P., Brickman, D., Pettigrew, B., Devine, L., Gosselin, A., Pettipas, R. G., and Lafleur, C.: Physical Oceanographic Conditions in the Gulf of St. Lawrence in 2011, DFO Can. Sci. Advis. Sec. Res. Doc., 2012/023, iii + 85 pp., Fisheries and Oceans Canada, 2012.

Galbraith, P. S., Chassé, J., Caverhill, C., Nicot, P., Gilbert, D., Pettigrew, B., Lefaivre, D., Brickman, D., Devine, L., and Lafleur, C.: Physical Oceanographic Conditions in the Gulf of St. Lawrence in 2015, DFO Can. Sci. Advis. Sec. Res. Doc., 2016/056, v +90 pp., Fisheries and Oceans Canada, 2016.

Gattuso, J.-P., Magnan, A., Bille, R., Cheung, W. W. L., Howes, E. L., Joos, F., Allemand, D., Bopp, L., Cooley, S. R., Eakin, C. M., Hoegh-Guldberg, O., Kelly, R. P., Portner, H.-O., Rogers, A. D., Baxter, J. M., Laffoley, D., Osborn, D., Rankovic, A., Rochette, J., Sumaila, U. R., Treyer, S., and Turley, C.: Contrasting futures for ocean and society from different anthropogenic $\mathrm{CO}_{2}$ emissions scenarios, Science, 349, aac4722, https://doi.org/10.1126/science.aac4722, 2015.

Green, D. H., Shenoy, D. M., Hart, M. C., and Hatton, A. D.: Coupling of dimethylsulfide oxidation to biomass production by a marine Flavobacterium, Appl. Environ. Microb., 77, 3137-3140, https://doi.org/10.1128/AEM.02675-10, 2011.
Grossart, H.-P., Allgaier, M., Passow, U., and Riebesell, U.: Testing the effect of $\mathrm{CO}_{2}$ concentration on the dynamics of marine heterotrophic bacterioplankton, Limnol. Oceanogr., 51, 111, https://doi.org/10.4319/lo.2006.51.1.0001, 2006.

Gunderson, A. R., Armstrong, E. J., and Stillman, J. H.: Multiple Stressors in a Changing World: The Need for an Improved Perspective on Physiological Responses to the Dynamic Marine Environment, Annu. Rev. Mar. Sci., 8, 357-378, https://doi.org/10.1146/annurev-marine-122414-033953, 2016.

Hansen, H. P. and Koroleff, F.: Determination of nutrients, in: Methods of Seawater Analysis, 3rd Edn., edited by: Grasshoff K., Kremling, K., and Ehrhardt, M., WileyVCH Verlag GmbH, Weinheim, Germany, 159-228, https://doi.org/10.1002/9783527613984.ch10, 2007.

Hatton, A. D., Darroch, L., and Malin, G.: The role of dimethylsulphoxide in the marine biogeochemical cycle of dimethylsulphide, Oceanogr. Mar. Biol., 42, 29-56, 2004.

Hopkins, F. E. and Archer, S. D.: Consistent increase in dimethyl sulfide (DMS) in response to high $\mathrm{CO}_{2}$ in five shipboard bioassays from contrasting NW European waters, Biogeosciences, 11, 4925-4940, https://doi.org/10.5194/bg-11-4925-2014, 2014.

Hopkins, F. E., Turner, S. M., Nightingale, P. D., Steinke, M., Bakker, D., and Liss, P. S.: Ocean acidification and marine trace gas emissions, P. Natl. Acad. Sci. USA, 107, 760-765, https://doi.org/10.1073/pnas.0907163107, 2010.

Hussherr, R., Levasseur, M., Lizotte, M., Tremblay, J.-É., Mol, J., Thomas, H., Gosselin, M., Starr, M., Miller, L. A., Jarniková, T., Schuback, N., and Mucci, A.: Impact of ocean acidification on Arctic phytoplankton blooms and dimethyl sulfide concentration under simulated ice-free and under-ice conditions, Biogeosciences, 14, 2407-2427, https://doi.org/10.5194/bg-142407-2017, 2017.

IPCC: Working Group I Contribution to the Fifth Assessment Report Climate Change 2013: The Physical Science Basis, Intergov. Panel Clim. Chang., 1535, https://doi.org/10.1017/CBO9781107415324, Cambridge University Press, Cambridge, 2013.

Iverson, R. L., Nearhoof, F. L., and Andreae, M. O.: Production of dimethylsulfonium propionate and dimethylsulfide by phytoplankton in estuarine and coastal waters, Limnol. Oceanogr., 34, 53-67, https://doi.org/10.4319/lo.1989.34.1.0053, 1989.

Karsten, U., Kück, K., Vogt, C., and Kirst, G. O.: Dimethylsulfoniopropionate production in phototrophic organisms and its physiological functions as a cryoprotectant, in: Biological and environmental chemistry of DMSP and related sulfonium compounds, edited by: Kiene, R. P., Visscher, P. T., Keller, M. D., and Kirst, G. O., Springer US, Boston, MA, 143-153, https://doi.org/10.1007/978-1-4613-0377-0, 1996.

Keller, M. D.: Dimethyl sulfide production and marine phytoplankton: the importance of species composition and cell size, Biol. Oceanogr., 6, 375-382, https://doi.org/10.1080/01965581.1988.10749540, 1989.

Kettle, A. J., Andreae, M. O., Amouroux, D., Andreae, T. W., Bates, T. S., Berresheim, H., Bingemer, H., Boniforti, R., Curran, M. A J., diTullio, G. R., Helas, G., Jones, G. B., Keller, I. M. D., Kiene, R. P., Leck, C., Levasseur, M., Maspero, M., Matrai, P., McTaggart, A. R., Mihalopoulos, N., Nguyen, B. C., Novo, A., Putaud, J. P., Rapsomanikis, S., Roberts, G., Schebeske, G., Sharma, S., Simó, R., Staubes, R., Turner, S., and Uher, G.: A global database 
of sea surface dimethylsulfide (DMS) measurements and a procedure to predict sea surface DMS as a function of latitude, longitude, and month, Global Biogeochem. Cy., 13, 399-444, 1999.

Kettles, N. L., Kopriva, S., and Malin, G.: Insights into the regulation of DMSP synthesis in the diatom Thalassiosira pseudonana through APR activity, proteomics and gene expression analyses on cells acclimating to changes in salinity, light and nitrogen, PLoS One, 9, https://doi.org/10.1371/journal.pone.0094795, 2014.

Kiene, R. P. and Linn, L. J.: Distribution and turnover of dissolved DMSP and its relationship with bacterial production and dimethylsulfide in the Gulf of Mexico, Limnol. Oceanogr., 45, 849-861, 2000.

Kiene, R. P. and Service, S. K.: Decomposition of dissolved DMSP and DMS in estuarine waters: dependence on temperature and substrate concentration, Mar. Ecol.-Prog. Ser., 76, 1-11, 1991.

Kiene, R. P., Linn, L. J., Gonzalez, J., Moran, M. A., and Bruton, J. A.: Dimethylsulfoniopropionate and methanethiol are important precursors of methionine and protein-sulfur in marine bacterioplankton, Appl. Environ. Microb., 65, 4549-4558, 1999.

Kiene, R. P., Linn, L. J., and Bruton, J. A.: New and important roles for DMSP in marine microbial communities, J. Sea. Res., 43, 209-224, 2000.

Kim, K. Y., Garbary, D. J., and Mclachlan, J. L.: Phytoplankton dynamics in Pomquet Harbour, Nova Scotia: a lagoon in the southern Gulf of St Lawrence, Phycologica, 43, 311-328, 2004.

Kim, J. M., Lee, K., Yang, E. J., Shin, K., Noh, J. H., Park, K. T., Hyun, B., Jeong, H. J., Kim, J. H., Kim, K. Y., Kim, M., Kim, H. C., Jang, P. G., and Jang, M. C.: Enhanced production of oceanic dimethylsulfide resulting from $\mathrm{CO}_{2}$-induced grazing activity in a high $\mathrm{CO}_{2}$ world, Environ. Sci. Technol., 44, 81408143, https://doi.org/10.1021/es102028k, 2010.

Kirst, G. O., Thiel, C., Wolff, H., Nothnagel, J., Wanzek, M., and Ulmke, R.: Dimethylsulfoniopropionate (DMSP) in ice-algae and its possible biological role, Mar. Chem., 35, 381-388, 1991.

Kwint, R. L. and Kramer, K. J.: Dimethylsulphide production by plankton communities, Mar. Ecol.-Prog. Ser., 121, 227-238, https://doi.org/10.3354/meps121227, 1995.

Hill, R. W., White, B. A., Cottrell, M. T., and Dacey, J. W. H.: Virusmediated total release of dimethylsulfoniopropionate from marine phytoplankton: a potential climate process, Aquat. Microb. Ecol., 14, 1-6, 1998.

Lana, A., Bell, T. G., Simó, R., Vallina, S. M., Ballabrera-Poy, J., Kettle, A. J., Dachs, J., Bopp, L., Saltzman, E. S., Stefels, J., Johnson, J. E., and Liss, P. S.: An updated climatology of surface dimethylsulfide concentrations and emission fluxes in the global ocean, Global Biogeochem. Cy., 25, 1-17, https://doi.org/10.1029/2010GB003850, 2011.

Laroche, D., Vézina, A. F., Levasseur, M., Gosselin, M., Stefels, J., Keller, M. D., Matrai, P. A., and Kwint, R. L. J.: DMSP synthesis and exudation in phytoplankton: A modeling approach, Mar. Ecol.-Prog. Ser., 180, 37-49, https://doi.org/10.3354/meps180037, 1999.

Lee, P. A., Saunders, P. A., De Mora, S. J., Deibel, D., and Levasseur, M.: Influence of copepod grazing on concentrations of dissolved dimethylsulfoxide and related sulfur compounds in the North Water, Northern Baffin Bay, Mar. Ecol.-Prog. Ser., 255, 235-248, https://doi.org/10.3354/meps255235, 2003.
Lee, P. A., Rudisill, J. R., Neeley, A. R., Maucher, J. M., Hutchins, D. A., Feng, Y., Hare, C. E., Leblanc, K., Rose, J. M., Wilhelm, S. W., Rowe, J. M., and Giacomo, R.: Effects of increased $p \mathrm{CO}_{2}$ and temperature on the North Atlantic spring bloom. III. Dimethylsulfoniopropionate, Mar. Ecol.-Prog. Ser., 388, 41-49, https://doi.org/10.3354/meps08135, 2009.

Le Quéré, C., Andres, R. J., Boden, T., Conway, T., Houghton, R. A., House, J. I., Marland, G., Peters, G. P., van der Werf, G. R., Ahlström, A., Andrew, R. M., Bopp, L., Canadell, J. G., Ciais, P., Doney, S. C., Enright, C., Friedlingstein, P., Huntingford, C., Jain, A. K., Jourdain, C., Kato, E., Keeling, R. F., Klein Goldewijk, K., Levis, S., Levy, P., Lomas, M., Poulter, B., Raupach, M. R., Schwinger, J., Sitch, S., Stocker, B. D., Viovy, N., Zaehle, S., and Zeng, N.: The global carbon budget 1959-2011, Earth Syst. Sci. Data, 5, 165-185, https://doi.org/10.5194/essd-5-1652013, 2013.

Le Quéré, C., Moriarty, R., Andrew, R. M., Canadell, J. G., Sitch, S., Korsbakken, J. I., Friedlingstein, P., Peters, G. P., Andres, R. J., Boden, T. A., Houghton, R. A., House, J. I., Keeling, R. F., Tans, P., Arneth, A., Bakker, D. C. E., Barbero, L., Bopp, L., Chang, J., Chevallier, F., Chini, L. P., Ciais, P., Fader, M., Feely, R. A., Gkritzalis, T., Harris, I., Hauck, J., Ilyina, T., Jain, A. K., Kato, E., Kitidis, V., Klein Goldewijk, K., Koven, C., Landschützer, P., Lauvset, S. K., Lefèvre, N., Lenton, A., Lima, I. D., Metzl, N., Millero, F., Munro, D. R., Murata, A., Nabel, J. E. M. S., Nakaoka, S., Nojiri, Y., O’Brien, K., Olsen, A., Ono, T., Pérez, F. F., Pfeil, B., Pierrot, D., Poulter, B., Rehder, G., Rödenbeck, C., Saito, S., Schuster, U., Schwinger, J., Séférian, R., Steinhoff, T., Stocker, B. D., Sutton, A. J., Takahashi, T., Tilbrook, B., van der Laan-Luijkx, I. T., van der Werf, G. R., van Heuven, S., Vandemark, D., Viovy, N., Wiltshire, A., Zaehle, S., and Zeng, N.: Global Carbon Budget 2015, Earth Syst. Sci. Data, 7, 349-396, https://doi.org/10.5194/essd-7-349-2015, 2015.

Levasseur, M., Michaud, S., Egge, J., Cantin, G., Nejstgaard, J. C., Sanders, R., Fernandez, E., Solberg, P. T., Heimdal, B., and Gosselin, M.: Production of DMSP and DMS during a mesocosm study of an Emiliania huxleyi bloom: Influence of bacteria and Calanus finmarchicus grazing, Mar. Biol., 126, 609-618, https://doi.org/10.1007/BF00351328, 1996.

Liss, P. S. and Lovelock, J. E.: Climate change: The effect of DMS emissions, Environ. Chem., 4, 377-378, https://doi.org/10.1071/EN07072, 2007.

Lizotte, M., Levasseur, M., Michaud, S., Scarratt, M. G., Merzouk, A., Gosselin, M., Pommier, J., Rivkin, R. B., and Kiene, R. P.: Macroscale patterns of the biological cycling of dimethylsulfoniopropionate (DMSP) and dimethylsulfide (DMS) in the Northwest Atlantic, Biogeochemistry, 110, 183-200, https://doi.org/10.1007/s10533-011-9698-4, 2012.

Lizotte, M., Levasseur, M., Law, C. S., Walker, C. F., Safi, K. A., Marriner, A., and Kiene, R. P.: Dimethylsulfoniopropionate (DMSP) and dimethyl sulfide (DMS) cycling across contrasting biological hotspots of the New Zealand subtropical front, Ocean Sci., 13, 961-982, https://doi.org/10.5194/os-13961-2017, 2017.

Lovelock, J. E., Maggs, R. J., and Rasmusse, R. A.: Atmospheric dimethyl sulfide and natural sulfur cycle, Nature, 237, 452-453, 1972.

Malin, G. and Kirst, G. O.: Algal production of dimethyl sulfide and its atmospheric role, J. Phycol., 33, 889-896, 1997. 
Malin, G., Wilson, W. H., Bratbak, G., Liss, P. S., and Mann, N. H.: Elevated production of dimethylsulfide resulting from viral infection of cultures of Phaeocystis pouchetii, Limnol. Oceanogr., 43, 1389-1393, https://doi.org/10.4319/lo.1998.43.6.1389, 1998.

Malmstrom, R. R., Kiene, R. P., Cottrell, M. T., and Kirchman, D. L.: Contribution of SAR11 bacteria to dissolved dimethylsulfoniopropionate and amino acid uptake in the north Atlantic Ocean, Appl. Environ. Microb., 70, 4129-4135, https://doi.org/10.1128/AEM.70.7.4129-4135.2004, 2004a.

Malmstrom, R. R., Kiene, R. P., and Kirchman, D. L.: Identification and enumeration of bacteria assimilating dimethylsulfoniopropionate (DMSP) in the North Atlantic and Gulf of Mexico, Limnol. Oceanogr., 49, 597-606, https://doi.org/10.4319/lo.2004.49.2.0597, 2004b.

Malmstrom, R. R., Kiene, R. P., Vila, M., and Kirchman, D. L.: Dimethylsulfoniopropionate (DMSP) assimilation by Synechococcus in the Gulf of Mexico and northwest Atlantic Ocean, Limnol. Oceanogr., 50, 1924-1931, https://doi.org/10.4319/1o.2005.50.6.1924, 2005.

Marie, D., Simon, N., and Vaulot, D.: Phytoplankton cell counting by flow cytometry, in: Algal Culturing Techniques, edited by: Anderssen, R. A., Elsevier Academic Press, Burlington, MA, USA, 253-267, https://doi.org/10.1016/B978-0120884261/50018-4, 2005.

Mucci, A., Levasseur, M., Gratton, Y., Martias, C., Scarratt, M., Gilbert, D., Tremblay, J.-É., Ferreyra, G., and Lansard, B.: Tidally-induced variations of $\mathrm{pH}$ at the head of the Laurentian Channel, Can. J. Fish. Aquat. Sci., 75, 1128-1141, https://doi.org/10.1139/cjfas-2017-0007, 2017.

Nguyen, B. C., Belviso, S., Mihalopoulos, N., Gostan, J., and Nival, P.: Dimethyl sulfide production during natural phytoplankton blooms, Mar. Chem., 24, 133-141, 1988.

Nightingale, P. D., Malin, G., Law, C. S., Watson, A. J., Liss, P. S., Liddicoat, M. I., Boutin, J., and Upstill-Goddard, R. C.: In situ evaluation of air-sea gas exchange parameterizations using novel conservative and volatile tracers, Global Biogeochem. Cy., 14, 373-387, 2000.

Niki, T., Kunugi, M., and Otsuki, A.: DMSP-lyase activity in five marine phytoplankton species: Its potential importance in DMS production, Mar. Biol., 136, 759-764, https://doi.org/10.1007/s002279900235, 2000.

Park, K. T., Lee, K., Shin, K., Yang, E. J., Hyun, B., Kim, J. M., Noh, J. H., Kim, M., Kong, B., Choi, D. H., Choi, S. J., Jang, P. G., and Jeong, H. J.: Direct linkage between dimethyl sulfide production and microzooplankton grazing, resulting from prey composition change under high partial pressure of carbon dioxide conditions, Environ. Sci. Technol., 48, 4750-4756, https://doi.org/10.1021/es403351h, 2014.

Parsons, T. R., Maita, Y., and Lalli, C. M.: A manual of chemical and biological methods for seawater analysis, Permagon Press, New York, 1984.

Paul, C., Sommer, U., Garzke, J., Moustaka-Gouni, M., Paul, A., and Matthiessen, B.: Effects of increased $\mathrm{CO}_{2}$ concentration on nutrient limited coastal summer plankton depend on temperature, Limnol. Oceanogr., 61, 853-868, https://doi.org/10.1002/lno.10256, 2016.

Pierrot, D. E., Lewis, E., and Wallace, D. W. R.: MS Excel program developed for $\mathrm{CO}_{2}$ system calculations, Carbon Dioxide
Information Analysis Center, ONRL/CDIAC-105a, Oak Ridge National Laboratory, US Department of Energy, Oak Ridge, Tennessee, USA, 2006.

Pinhassi, J., Simó, R., González, J. M., Vila, M., Alonso-Sáez, L., Kiene, R. P., Moran, M. A., and Pedrós-Alió, C.: Dimethylsulfoniopropionate turnover is linked to the composition and dynamics of the bacterioplankton assemblage during a microcosm phytoplankton bloom, Appl. Environ. Microb., 71, 7650-7660, https://doi.org/10.1128/AEM.71.12.7650-7660.2005, 2005.

Quinn, P. K. and Bates, T. S.: The case against climate regulation via oceanic phytoplankton sulphur emissions, Nature, 480, 51-6, https://doi.org/10.1038/nature10580, 2011.

Quinn, P. K., Coffman, D. J., Johnson, J. E., Upchurch, L. M., and Bates, T. S.: Small fraction of marine cloud condensation nuclei made up of sea spray aerosol, Nat. Geosci., 10, 674-679, https://doi.org/10.1038/ngeo3003, 2017.

R Core Team: R: A language and environment for statistical computing. R Foundation for Statistical Computing, Vienna, Austria, available at: https://www.R-project.org/ (last access: 25 February 2019), 2016

Riebesell, U. and Gattuso, J. P.: Lessons learned from ocean acidification research, Nat. Clim. Change, 5, 12-14, https://doi.org/10.1038/nclimate2456, 2015.

Robert-Baldo, G., Morris, M., and Byrne, R.: Spectrophotometric determination of seawater $\mathrm{pH}$ using phenol red, Anal. Chem., 3, 2564-2567, https://doi.org/10.1021/ac00290a030, 1985.

Roemmich, D., Church, J., Gilson, J., Monselesan, D., Sutton, P., and Wijffels, S.: Unabated planetary warming and its ocean structure since 2006, Nat. Clim. Change, 5, 240-245, https://doi.org/10.1038/nclimate2513, 2015.

Royer, S. J., Levasseur, M., Lizotte, M., Arychuk, M., Scarratt, M. G., Wong, C. S., Lovejoy, C., Robert, M., Johnson, K., Peña, A., Michaud, S., and Kiened, R. P.: Microbial dimethylsulfoniopropionate (DMSP) dynamics along a natural iron gradient in the northeast subarctic Pacific, Limnol. Oceanogr., 55, 1614-1626, https://doi.org/10.4319/lo.2010.55.4.1614, 2010.

Ruiz-González, C., Galí, M., Gasol, J. M., and Simó, R.: Sunlight effects on the DMSP-sulfur and leucine assimilation activities of polar heterotrophic bacterioplankton, Biogeochemistry, 110, 5774, https://doi.org/10.1007/s10533-012-9699-y, 2012.

Scarratt, M. G., Levasseur, M., Schultes, S., Michaud, S., Cantin, G., Vézina, A., Gosselin, M., and De Mora, S. J.: Production and consumption of dimethylsulfide (DMS) in North Atlantic waters, Mar. Ecol.-Prog. Ser., 204, 13-26, https://doi.org/10.3354/meps204013, 2000.

Schlüter, L., Lohbeck, K. T., Gröger, J. P., Riebesell, U., and Reusch, T. B. H.: Long-term dynamics of adaptive evolution in a globally important phytoplankton species to ocean acidification, Sci. Adv., 2, e1501660, https://doi.org/10.1126/sciadv.1501660, 2016.

Schwinger, J., Tjiputra, J., Goris, N., Six, K. D., Kirkevåg, A., Seland, Ø., Heinze, C., and Ilyina, T.: Amplification of global warming through $\mathrm{pH}$ dependence of DMS production simulated with a fully coupled Earth system model, Biogeosciences, 14, 3633-3648, https://doi.org/10.5194/bg-14-3633-2017, 2017.

Simó, R.: Production of atmospheric sulfur by oceanic plankton: Biogeochemical, ecological and evolutionary links, Trends Ecol. Evol., 16, 287-294, https://doi.org/10.1016/S01695347(01)02152-8, 2001. 
Simó, R.: From cells to globe: approaching the dynamics of DMS(P) in the ocean at multiple scales, Can. J. Fish. Aquat. Sci., 61, 673-684, https://doi.org/10.1139/f04-030, 2004.

Simó, R. and Pedrós-Alió, C.: Role of vertical mixing in controlling the oceanic production of dimethyl sulphide, Nature, 402, 396399, https://doi.org/10.1038/46516, 1999.

Six, K. D., Kloster, S., Ilyina, T., Archer, S. D., Zhang, K., and Maier-Reimer, E.: Global warming amplified by reduced sulphur fluxes as a result of ocean acidification, Nat. Clim. Change, 3, 975-978, https://doi.org/10.1038/nclimate1981, 2013.

Spiese, C. E., Kieber, D. J., Nomura, C. T., and Kiene, R. P.: Reduction of dimethylsulfoxide to dimethylsulfide by marine phytoplankton, Limnol. Oceanogr., 54, 560-570, https://doi.org/10.4319/lo.2009.54.2.0560, 2009.

Starr, M., St-Amand, L., Devine, L., Bérard-Therriault, L., and Galbraith, P. S.: State of phytoplankton in the Estuary and Gulf of St. Lawrence during 2003, CSAS Res. Doc., 2004/123, 35, 2004.

Stefels, J.: Physiological aspects of the production and conversion of DMSP in marine algae and higher plants, J. Sea Res., 43, 183 197, https://doi.org/10.1016/S1385-1101(00)00030-7, 2000.

Stefels, J. and Van Boekel, W. H. M.: Production of DMS from dissolved DMSP in axenic cultures of the marine phytoplankton species Phaeocystis sp., Mar. Ecol.-Prog. Ser., 97, 11-18, https://doi.org/10.3354/meps097011, 1993.

Stefels, J., Steinke, M., Turner, S., Malin, G., and Belviso, S.: Environmental constraints on the production and removal of the climatically active gas dimethylsulphide (DMS) and implications for ecosystem modelling, Biogeochemistry, 83, 245-275, https://doi.org/10.1007/s10533-007-9091-5, 2007.

Steinke, M., Malin, G., Archer, S. D., Burkill, P. H., and Liss, P. S.: DMS production in a coccolithophorid bloom: Evidence for the importance of dinoflagellate DMSP lyases, Aquat. Microb. Ecol., 26, 259-270, https://doi.org/10.3354/ame026259, 2002.

Stillman, J. H. and Paganini, A. W.: Biochemical adaptation to ocean acidification, J. Exp. Biol., 218, 1946-1955, https://doi.org/10.1242/jeb.115584, 2015.

Sunda, W., Kieber, D. J., Kiene, R. P., and Huntsman, S.: An antioxidant function for DMSP and DMS in marine algae, Nature, 418, 317-320, 2002.

Toole, D. A. and Siegel, D. A.: Light-driven cycling of dimethylsulfide (DMS) in the Sargasso Sea: closing the loop, Geophys. Res. Lett., 31, 1-4, https://doi.org/10.1029/2004GL019581, 2004.

Toole, D. A., Slezak, D., Kiene, R. P., Kieber, D. J., and Siegel, D. A.: Effects of solar radiation on dimethylsulfide cycling in the western Atlantic Ocean, Deep-Sea Res. Pt. I, 53, 136-153, https://doi.org/10.1016/j.dsr.2005.09.003, 2006.

Toole, D. A., Siegel, D. A., and Doney, S. C.: A light-driven, one-dimensional dimethylsulfide biogeochemical cycling model for the Sargasso Sea, J. Geophys. Res.-Biogeo., 113, 1-20, https://doi.org/10.1029/2007JG000426, 2008.

Vallina, S. M., Simó, R., Anderson, T. R., Gabric, A., Cropp, R., and Pacheco, J. M.: A dynamic model of oceanic sulfur (DMOS) applied to the Sargasso Sea: Simulating the dimethylsulfide (DMS) summer paradox, J. Geophys. Res.-Biogeo., 113, G01009, https://doi.org/10.1029/2007JG000415, 2008.
Vila, M., Simó, R., Kiene, R. P., Pinhassi, J., González, J. M., Moran, M. A., and Pedrós-Alió, C.: Use of microautoradiography combined with fluorescence in situ hybridization to determine dimethylsulfoniopropionate incorporation by marine bacterioplankton taxa, Appl. Environ. Microb., 70, 4648-4657, https://doi.org/10.1128/AEM.70.8.4648-4657.2004, 2004.

Vila-Costa, M., Simó, R., Harada, H., Gasol, J. M., Slezak, D., and Kiene, R. P.: Dimethylsulfoniopropionate Uptake by Marine Phytoplankton, Science, 314, 652-654, 2006 a.

Vila-Costa, M., Del Valle, D. A., González, J. M., Slezak, D., Kiene, R. P., Sánchez, O., and Simó, R.: Phylogenetic identification and metabolism of marine dimethylsulfide consuming bacteria, Environ. Microbiol., 8, 2189-2200, https://doi.org/10.1111/j.14622920.2006.01102.x, 2006b.

Vila-Costa, M., Pinhassi, J., Alonso, C., Pernthaler, J., and Simó, R.: An annual cycle of dimethylsulfoniopropionate sulfur and leucine assimilating bacterioplankton in the coastal NW Mediterranean, Environ. Microbiol., 9, 2451-2463, https://doi.org/10.1111/j.1462-2920.2007.01363.x, 2007.

Vogt, M., Steinke, M., Turner, S., Paulino, A., Meyerhöfer, M., Riebesell, U., LeQuéré, C., and Liss, P.: Dynamics of dimethylsulphoniopropionate and dimethylsulphide under different $\mathrm{CO}_{2}$ concentrations during a mesocosm experiment, Biogeosciences, 5, 407-419, https://doi.org/10.5194/bg-5-407-2008, 2008.

Webb, A., Malin, G., Hopkins, F., Ho, K. L., Riebesell, U., Schulz, K., Larsen, A., and Liss, P.: Ocean acidification has different effects on the production of DMS and DMSP measured in cultures of Emiliania huxleyi and a mesocosm study: a comparison of laboratory monocultures and community interactions, Environ. Chem., 13, 314-329, https://doi.org/10.1071/EN14268, 2015.

Webb, A. L., Leedham-Elvidge, E., Hughes, C., Hopkins, F. E., Malin, G., Bach, L. T., Schulz, K., Crawfurd, K., Brussaard, C. P. D., Stuhr, A., Riebesell, U., and Liss, P. S.: Effect of ocean acidification and elevated fCO 2 on trace gas production by a Baltic Sea summer phytoplankton community, Biogeosciences, 13, 45954613, https://doi.org/10.5194/bg-13-4595-2016, 2016.

Wolfe, G. V. and Steinke, M.: Grazing-activated production of dimethyl sulfide (DMS) by two clones of Emiliania huxleyi, Limnol. Oceanogr., 41, 1151-1160, https://doi.org/10.4319/lo.1996.41.6.1151, 1996.

Woodhouse, M. T., Mann, G. W., Carslaw, K. S., and Boucher, O.: Sensitivity of cloud condensation nuclei to regional changes in dimethyl-sulphide emissions, Atmos. Chem. Phys., 13, 2723 2733, https://doi.org/10.5194/acp-13-2723-2013, 2013.

Yoch, D. C.: Dimethylsulfoniopropionate: Its sources, role in the marine food web, and biological degradation to dimethylsulfide, Appl. Environ. Microb., 68, 5804-5815, https://doi.org/10.1128/AEM.68.12.5804-5815.2002, 2002. 